\title{
Single Nucleotide Polymorphisms in 25-Hydroxyvitamin D3 1-Alpha-Hydroxylase (CYP27B1) Gene: The Risk of Malignant Tumors and Other Chronic Diseases
}

\author{
Maria Latacz ${ }^{1,2} ®$, Jadwiga Snarska ${ }^{3,4}$, Elżbieta Kostyra ${ }^{1}$, Ewa Fiedorowicz ${ }^{1}$, \\ Huub F. J. Savelkoul ${ }^{5}$, Roman Grzybowski ${ }^{6,7}$ and Anna Cieślińska ${ }^{1, *(D)}$ \\ 1 Faculty of Biology and Biotechnology, University of Warmia and Mazury, 10-719 Olsztyn, Poland; \\ mmlatacz@gmail.com (M.L.); elzbieta.kostyra@uwm.edu.pl (E.K.); ewa.kuzbida@uwm.edu.pl (E.F.) \\ 2 Faculty of Medicine, Collegium Medicum, University of Warmia and Mazury in Olsztyn, \\ 10-082 Olsztyn, Poland \\ 3 Department of General Surgery, Faculty of Medical Sciences, Collegium Medicum, University of Warmia \\ and Mazury, 10-082 Olsztyn, Poland; jadwiga.snarska@uwm.edu.pl \\ 4 Independent Public Healthcare Center of Ministry of Internal Affairs and Administration with the Warmia \\ and Mazury, Center of Oncology in Olsztyn, 10-228 Olsztyn, Poland \\ 5 Cell Biology and Immunology Group Wageningen University and Research, $6700 \mathrm{AH}$ Wageningen, \\ The Netherlands; huub.savelkoul@wur.nl \\ 6 Clinical Department of Trauma-Orthopedic Surgery and Spine Surgery of the Provincial Specialist Hospital \\ in Olsztyn, 10-561 Olsztyn, Poland; romek.grzybowski@wp.pl \\ 7 Clinical Department of Orthopedics, Traumatology and Spine Surgery, Collegium Medicum, University of \\ Warmia and Mazury, 10-719 Olsztyn, Poland \\ * Correspondence: anna.cieslinska@uwm.edu.pl; Tel.: +48-89-523-36-67
}

Received: 29 February 2020; Accepted: 16 March 2020; Published: 18 March 2020

\begin{abstract}
Vitamin D is widely known for its roles in the promotion of apoptosis and differentiation, with simultaneous inhibition of proliferation, inflammation, angiogenesis, invasion, and metastasis. Modern literature lacks complete information on polymorphisms in CYP27B1, the only enzyme capable of vitamin D activation. This review presents gathered data that relate to genetic variants in CYP27B1 gene in correlation to multiple diseases, mostly concerning colorectal, prostate, breast, lung, and pancreatic cancers, as well as on other pathologies, such as non-Hodgkin's lymphoma, oral lichen planus, or multiple sclerosis.
\end{abstract}

Keywords: vitamin D; single nucleotide polymorphism; CYP27B1; chronic diseases; colorectal cancer; breast cancer; prostate cancer; multiple sclerosis

\section{Introduction}

\subsection{Vitamin D in Malignancies}

Numerous basic and preclinical studies have suggested a strong relationship between the role of vitamin $\mathrm{D}$ in various cancer processes, while different results have been obtained in epidemiological studies and clinical trials [1].

In the 1980s, several discoveries substantiated the effects of vitamin D on the immune system and important processes in cancer development [2]. In the Suda lab, it was shown that a significant physiological concentration of calcitriol could induce a response in cells unrelated to calcium and phosphate metabolism, as well as stimulate cell maturation of mouse myeloid cells into mature 
macrophages [2,3]. In addition, a description of an anephtertic patient showed elevated levels of calcitriol and development of secondary hypercalcemia, while macrophages in granulomas in patients with sarcoidosis were found to be responsible for this condition [2,4]. In the study, Provvedini et al. obtained results indicating the presence of vitamin D receptors (VDR) in monocytes and its absence in resting peripheral $\mathrm{T}$ and $\mathrm{B}$ lymphocytes [5]. At the same time, it was possible to induce VDR expression in lymphocytes in response to mitogen or specific antigens, while VDR expression was detected in cancer lymphoma cells. Thus, cells can respond to the presence of $1,25(\mathrm{OH})_{2} \mathrm{D}[2,5]$, and Colston et al. (1981) proved the anti-cancer effects of calcitriol by inhibiting proliferation of malignant melanoma cells [6]. Until now, the pleiotropic activity of bio-active calcitriol (vitamin $\mathrm{D}_{3}$ ) has been demonstrated in 6 different areas that are important for carcinogenesis (Figure 1).

\begin{tabular}{|c|c|c|c|c|c|}
\hline & \multicolumn{4}{|c|}{ Action of calcitriol $1,25(\mathrm{OH})_{2} \mathrm{D}_{3}$} & \\
\hline Proliferation & Differentiation & Apoptosis & Inflammation & Angiogenesis & $\begin{array}{l}\text { Invasion and } \\
\text { metastasis }\end{array}$ \\
\hline $\begin{array}{l}\text { p } 21 \text { and p27 } \\
\text { expression } \\
\downarrow \text { CDKs, } \\
\text { cyclins, MYC } \\
\text { expression }\end{array}$ & $\begin{array}{l}\text { A caesin, } \\
\text { adhesion } \\
\text { proteins, lipids, } \\
\text { PSA, prostate } \\
\text { differentiation } \\
\text { factor, } \\
\text { E-cadherin } \\
\text { and other } \\
\text { differentiation } \\
\text { factors } \\
\text { expression }\end{array}$ & $\begin{array}{l}\wedge \mathrm{BAX} \\
\downarrow \mathrm{BCL}-2\end{array}$ & $\begin{array}{l}\downarrow P G \text { receptors, } \\
\text { stress kinase, } \\
\text { COX2 } \\
\text { expression } \\
\text { PMAPKP5, } \\
15-P G D H \\
\text { expression }\end{array}$ & $\begin{array}{l}\text { level of HIF1 } \alpha \text {, } \\
\text { VEGF, IL-8, } \\
\text { tenascin C, } \\
\text { PGE }_{2}\end{array}$ & $\begin{array}{l}\downarrow \text { MMP9, } \\
\text { plasminogen } \\
\text { activator, } \alpha 6 \\
\text { and } \beta 4 \text { integrin } \\
\text { expression } \\
\text { E-cadherin, } \\
\text { TIMP1 } \\
\text { expression }\end{array}$ \\
\hline
\end{tabular}

\section{$\uparrow$ - increase \\ $\downarrow$ - decrease}

CDK, cyclin-dependent kinase; MYC, proto-oncogene; PSA, prostate-specific antigen; $B A X, B C L$-2-associated $X$ protein; $\mathrm{BCL}-2$, B-cell lymphoma 2; PG, prostaglandin; COX2, cyclooxygenase 2; MAPKP5, mitogen-activated protein kinase phosphatase 5; $15-P G D H, 15$-hydroxyprostaglandin dehydrogenase; HIF1 $\alpha$, hypoxiainducible factor $1 \alpha$; VEGF, vascular endothelial growth factor; $\mathrm{IL}-8$, interleukin 8; $\mathrm{PGE}_{2}$, prostaglandin $\mathrm{E}_{2} ; \mathrm{MMP9}$, matrix metalloproteinase 9; TIMP1, tissue inhibitor of metalloproteinases 1.

Figure 1. The different effects of calcitriol (the bio-active form of vitamin D) on the human body (based on Feldman et al. 2014 [1], with own modifications).

Increase in the expression of $p 21$ and $p 27$ with a concomitant decrease in cyklin-dependent kinases (CDks), cyclins, MYC (proto-oncogene) expression inhibits the proliferation of tumor cells. The observed increase in BCL-2-associated X protein (BAX) and decrease in BCL-2 (B-cell lymphoma 2) expression promotes the induction of apoptosis.

For sporadic colorectal cancer, the presence of calcitriol has an inhibitory effect on $\beta$-catenin transcriptional activity, and thus on the whole activation pathway, which is the most common change in this particular cancer [1,7]. The development of postmenopausal estrogen receptor (ER)+ breast cancer is driven by local synthesis of estrogen, while calcitriol acts as a suppressor of aromatase expression (important in the synthesis of estrogen) [8] and downregulator of ER receptors [1,9]. In addition, the growth of prostate cancer is induced by the activity of androgens (AR). An interaction between the active form of vitamin $D$ and AR, for example, results in the regulation of the AR catabolism [10] and of the expression of the $A R$ gene [11] and the VDR gene [1,12]. Calcitriol might also have an effect on cancer stem cells, especially those in prostate and breast cancers [1].

All of these described actions of vitamin D pertain to its active form, while 25-hydroxyvitamin D3 1-alpha-hydroxylase (CYP27B1) is the only enzyme capable of transferring the inactive form $25(\mathrm{OH}) \mathrm{D}$ into the active $1,25(\mathrm{OH})_{2} \mathrm{D}$ form (Figure 2). 


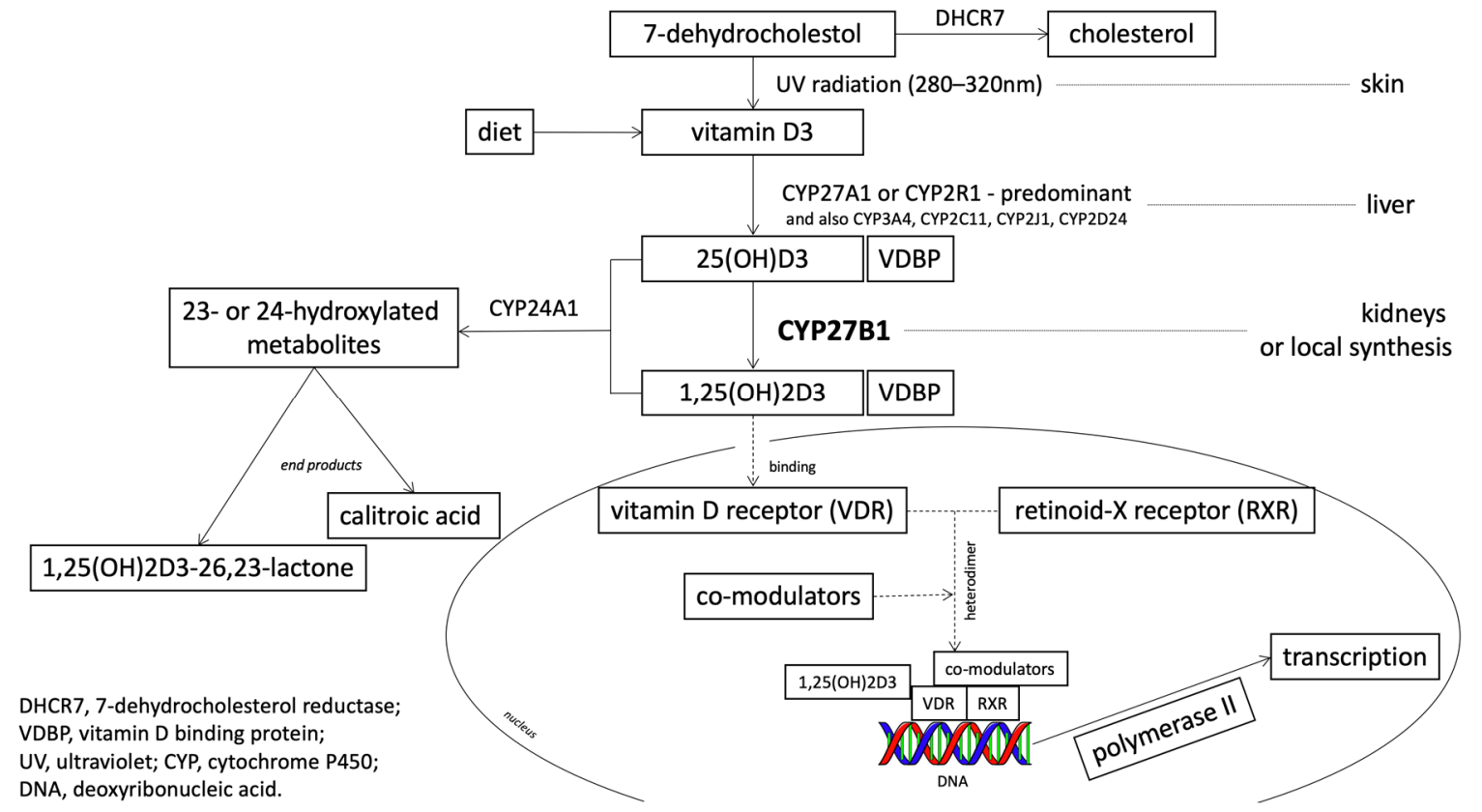

Figure 2. Location of CYP27B1 activity in the metabolic pathway of vitamin D (based on Jenkinson 2019 [13] and Feldman et al. 2014 [1], with own modifications).

Current literature lacks a summary of existing knowledge about mutations occurring in this CYP27B1 gene. The first report on linking genetic variation in the key genes of vitamin D metabolism documented the different bone density related to various allelic forms of the vitamin D receptor $(V D R)[14,15]$. The polymorphisms present in VDR are the most often studied with respect to the correlation with the presence of specific diseases [16]. The biologically active form of vitamin D has an inhibitory effect on angiogenesis, causes G0/G1 cell cycle arrest, induces apoptosis, increases cell differentiation, and inhibits various signalling pathways in the tumor cell [17]. It is estimated that vitamin D contributes to the expression of 3-5\% of genes, including many that are related to cancer [17]. Vitamin D deficiency can affect the development of diseases such as type II diabetes, cardiovascular disease, autoimmune disease, and neoplasms [18]. The plasma level of $25(\mathrm{OH}) \mathrm{D}$ is the most commonly used biomarker for assessing vitamin D status from both endogenous synthesis and supplementation [19]. It was assumed that the plasma concentration level of $25(\mathrm{OH}) \mathrm{D}$ is an adequate indicator of the supply of vitamin D in the body [20].

\subsection{5-Hydroxyvitamin D3 1-Alpha-Hydroxylase (CYP27B1): The Gene and the Enzyme}

It is known that 25-Hydroxyvitamin D3 1-alpha-hydroxylase (CYP27B1, cytochrome p450 27B1) encodes the cytochrome P450 enzyme. The location of the gene is at 12q14.1 on the long arm of chromosome 12. Several studies have confirmed that the gene contains 9 exons, but the obtained sum of lengths of exons varies between them [21-23]. The enzyme represents a family of 450 cytochromes and is classified as a mitochondrial enzyme. The product of translation is a protein containing approximately 508 amino acids, with an N-terminal mitochondrial signal sequence and a heme binding site [21]. Many single nucleotide polymorphisms (SNPs) were identified in the CYP27B1 gene, with different effects in amino acid sequence changes (Figure 3). 

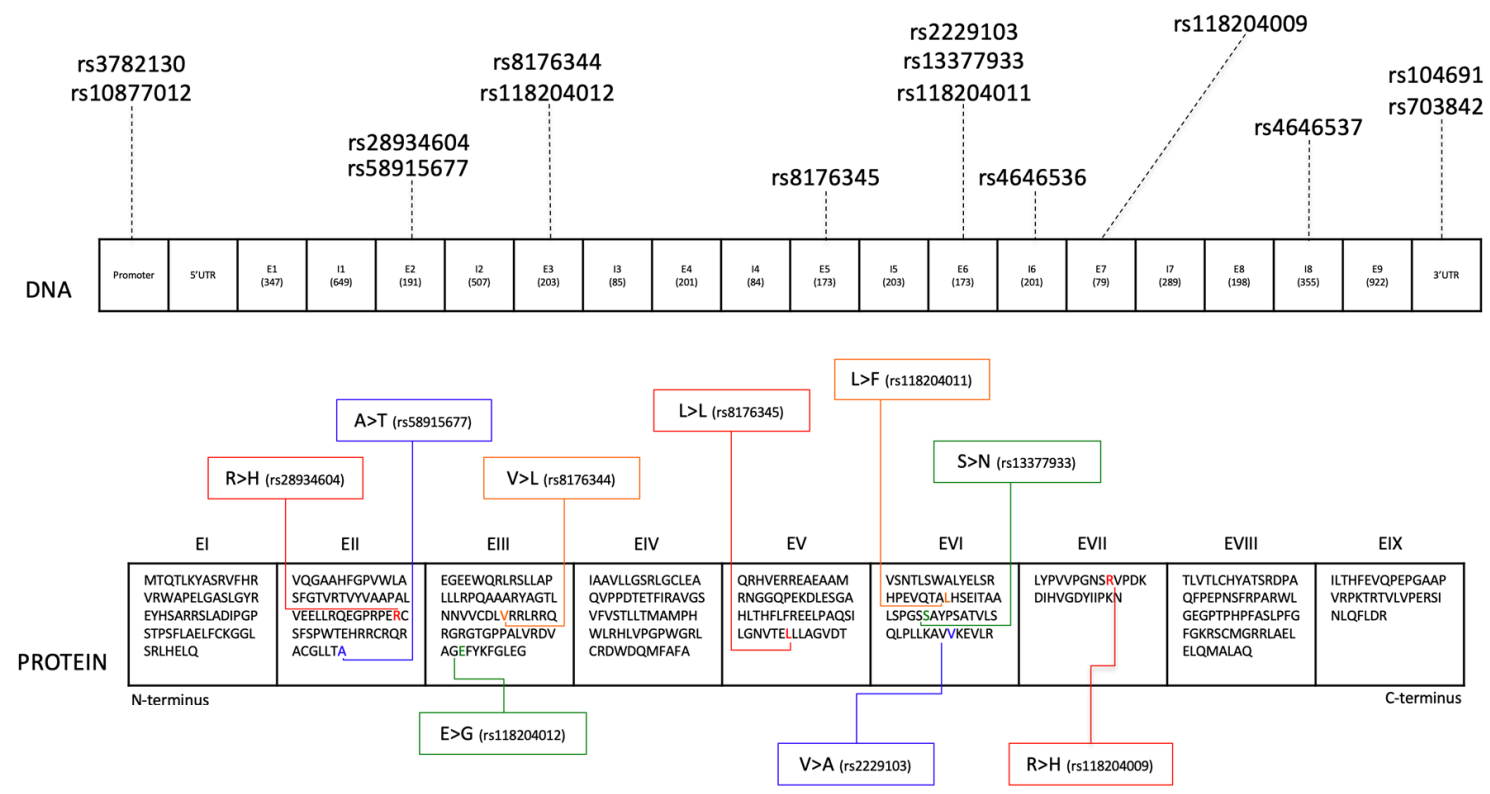

Single nucleotide polymorphisms in CYP27B1 gene.

DNA: I - intron, E - exon, the number in the brackets represents the number of base pairs in a gene fragment.

Protein: the amino acid sequence is represented by the single amino acid names; colourful boxes indicate which amino acid could be found at the polymorphic site.

Amino acid: G, Glycine; P, Proline; A, Alanine; V, Valine; L, Leucine; I, Isoleucine; M, Methionine; C, Cysteine; F, Phenylalanine; Y, Tyrosine; W, Tryptophan; H, Histidine; K, Lysine; R, Arginine; Q, Glutamine; N, Asparagine; E, Glutamic Acid; D, Aspartic Acid; S, Serine; T, Threonine.

Figure 3. Single nucleotide polymorphisms in amino acid sequences of the CYP27B1 gene.

The role of CYP27B1 is the hydroxylation of $25(\mathrm{OH}) \mathrm{D}$ at position $\mathrm{C} 1$ and the formation of a biologically active form of vitamin D (the so-called calcitriol). Kidneys are indicated as the main source of the enzyme. There are two independent synthesis sites within this organ: the proximal straight tubules and the proximal convoluted tubules $[24,25]$. The regulation in the proximal straight tubules occurs under the influence of calcitonin (a hormone produced by thyroid C cells), while in proximal convoluted tubules it is a parathyroid hormone that engages cAMP as a signal transducer.

Although the enzyme CYP27B1 initially referred only to renal tissues, its presence has been also been determined in numerous other cells from different systems, including dendritic cells, parathyroid cells, osteoblasts, osteoclasts, keratinocyte, mammary epithelial cells, renal tubular cells, pancreatic beta cells, vascular endothelial cells, and prostate epithelial cells [2] (Figure 4). Apart from the activities mentioned above, macrophages also actively express this enzyme, and with granulomata-forming diseases (different infectious, non-infectious, and neoplastic diseases) the production of the enzyme is elevated to a level that it dysregulates calcium homeostasis [26].

In addition to macrophages, only the placenta is capable of non-renal $1,25(\mathrm{OH})_{2} \mathrm{D}$ synthesis in such large quantities that it causes an increase in its concentration in the blood and has an endocrine effect [26]. However, it is suggested that the role of placental calcitriol is to modulate the fetal immune response, and it is the fetal kidneys that are responsible for the calcium-phosphate metabolism [27].

The regulation of CYP27B1 expression also involves other mechanisms, depending on its renal or extrarenal origin. In the kidneys, it is controlled by the parathyroid hormone (PTH) and fibroblast growth factor 23 (FGF23), while additionally there is a negative feedback between $25(\mathrm{OH}) \mathrm{D}$ and $1,25(\mathrm{OH})_{2} \mathrm{D}$ synthesis. Extrarenal CYP27B1 expression is upregulated by the presence of pro-inflammatory cytokines, such as interleukin 15 (IL-15) or interferon gamma, and is also stimulated by an increased level of 25(OH)D [26]. 


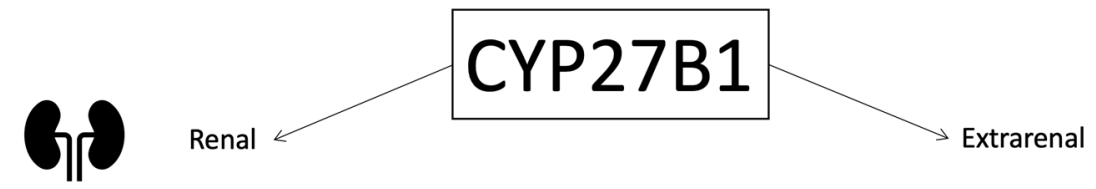

- Upregulation of gene expression: PTH (parathyroid hormone), low level of $250 \mathrm{HD}$

- Downregulation of gene expression: FGF23 (fibroblast growth factor 23), high calcium concentration, high phosphate concentration, high 250HD level

- Endocrine signalling

- Main function: bone mineralization
- Upregulation of gene expression: high 250HD level

- Autocrine or paracrine signalling; only has endocrine effect in placenta and macrophages

- Main function: immunomodulation

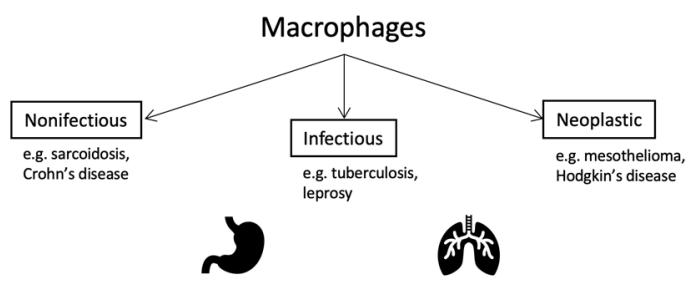

Figure 4. Different roles of CYP27B1 in the human body (based on Adams and Hewison 2012 [26], with own modifications).

\subsection{CYP27B1 and Cancer}

The expression of CYP27B1 and activity of the enzyme in cancerous cells varies depending on the study, either increasing, decreasing, or remaining at the same level [1]. This can be influenced by the grade of tumor, reflecting the abnormality of the tumor cells and tissue, and the probability of growth and spreading behavior of the tumor. Well-differentiated tumors tend to express a higher level of the enzyme than those that are poorly differentiated with an aggressive course of the disease [28].

\subsection{Colorectal Cancer (CRC)}

Most studies tend to conclude that higher levels of vitamin D are negatively correlated with the risk of colorectal neoplasia [29-32]. By demonstrating that intestinal cells from the large intestine synthesize 1- $\alpha$-hydroxylase and can convert vitamin D into an active paracrine and autocrine form [33], the influence of the CYP27B1 polymorphism on the resulting vitamin D level in plasma has become a potential subject of research to determine the risk of the occurrence of colon cancer [34]. It has already been proven that genetic variants occurring within CYP27B1 increase the risk of colorectal cancer [35]. Alongside the development of the stage of cancer (the appearance of less differentiated cells), decreased expression of the examined gene was observed [36]. It is worth noting that at the very beginning of the tumor transformation, the level of expression is raised compared unchanged neoplastic cells [36]. The effect of vitamin D on the development of colorectal cancer is caused by the inhibition of angiogenesis and activity of the Wnt pathway. Moreover, this pathway also affects the process of angiogenesis and consequently decreases it even more [1,37].

Interestingly, the results indicating the significance of vitamin D were obtained in the winter period, when higher mortality rates occurred after diagnosing the cancer. This period is characterized by vitamin D deficiency compared to individuals diagnosed at the turn of summer and autumn, when higher plasma levels of 25(OH)D were noted [38].

Although a genome-wide association study (GWAS) did not show a relationship between variability within the CYP27B1 gene and the circulating levels of 25(OH)D [39], two other studies confirmed that the rs10877012 polymorphism is related to the level of 25(OH)D circulating in the blood [40,41]. The results concerning the occurrence and the effects of this polymorphism are contradictory. During vitamin D supplementation, the influence of this polymorphism on the level of any of the vitamin D metabolites could not be demonstrated, and therefore the researchers rejected this hypothesis without 
examining the vitamin D levels during supplementation [20]. Supplementation of vitamin D in patients with CRC caused an increase in the plasma level of $25(\mathrm{OH}) \mathrm{D}$, however in the case of $1,25(\mathrm{OH})_{2} \mathrm{D}$, this supplementation effect on elevated levels was not observed, which may be caused by the very close mutual control of the level of $1,25(\mathrm{OH})_{2} \mathrm{D}$ by both enzymes CYP27B1 and CYP24A1 [20]. Only in the case of hypercalcemia was the calcitriol level increased [42].

Cancers of the proximal and distal parts of the large intestine differ from each other at the molecular level [43]. The proximal part is supplied by the superior mesenteric artery, whereas the distal part is supplied by the inferior mesenteric artery; additionally, lymphatic drainage is carried out by different nodes and the thinner mucous membrane is characteristic of the distal part [44-46]. The regulation at the gene level of CYP27B1 in the mucosa differs between these parts of the intestine [47]. The question arises of whether the risk of cancer varies depending on the location in the large intestine, considering the metabolism of vitamin D [48]. When testing the polymorphism of rs4646536, there was no greater risk to any of the genotypes, while in the same study the interaction with CYP24A1 (the presence of a TT homozygote at rs4646536 polymorphic site in combination with at least one rare $\mathrm{G}$ allele in rs2259735) was shown to reduce the risk of distal colon cancer development $(\mathrm{OR}=0.51$, 95\% CI: 0.33-0.81) [35]. For individuals with at least one rare C allele in rs4646536 and longer exposure to sun-derived UV rays (in the study this was exposure equal to $75 \mathrm{UV}$ index hours), the risk of cancer of the proximal colon cancer decreased ( $\mathrm{OR}=0.86,95 \% \mathrm{CI}: 0.74-1.00)$ [35]. Despite the detection of a statistical dependence, this variant is found in a poorly conserved region and strong linkage disequilibrium occurs between this and another variant occurring in the $5^{\prime}$ promoter region of the CYP27B1 gene [35]; the functional significance of both variants is unknown, but because of their location they may play a role in transcription or translation [49].

Another study reviewed the impact of polymorphisms on the synthesis of active enzymes in colorectal cancer cells (rs28934604-R107H, rs58915677-A129T, rs8176344-V166L, rs13377933-S356N, rs2229103-V374A) [50]; they all occur within the active domain of the enzyme that contains the porphyrin ring [51]. Apart from rs8176344 polymorphism, all others significantly reduced the enzymatic activity [50]. Among those four polymorphisms, the most significant difference was recorded at rs28934604 and rs13377933. Although the first one is quite rare, it has been thoroughly examined because it is one of the four etiologic factors in rickets development due to the pseudo-deficiency of vitamin D [22]. The next one is a poorly understood polymorphism, whereby its strong influence on the functions of the enzyme means it is a rare genetic variant [50]. Wild type rs58915677 and rs2229103 caused a decrease in CYP27B1 level in this tumor. These are poorly understood polymorphisms and the association of minor allele frequency (MAF) for a specific race has not been established yet, although it was concluded that the rs229103 polymorphism is considered harmful [50,52]. The polymorphism rs 8176344 showed increased activity at high doses of $25(\mathrm{OH}) \mathrm{D}$ [53]. However, when the substrate concentration remained at a normal level, no increase in synthesis was observed compared to the wild type; such result may indicate a difference in administered doses of vitamin D that should occur in people with various genotypes [50].

The collected data indicate a protective role of calcium from the diet in the development of colorectal cancer [54]. Vitamin D (well-known for its role in maintaining calcium homeostasis) has a binding site within the calcium-sensing receptor (CASR) promoter, which links these two molecules at the molecular level [55]. Potentially the interaction between the variants in CASR and in the CYP27B1 genotypes, which activates the ligand for the CASR promoter, could contribute to the etiology of cancer, however this has not been demonstrated yet [55].

As has already been mentioned, vitamin $\mathrm{D}$ has protective effects against the development of colon cancer [56-60]. Among many factors, skin color affects the level of this molecule, and thereby this is associated with an increased risk of cancer [61]. The effects of CYP27B1 polymorphisms on African Americans were analyzed. The study of the two polymorphisms (which in previous studies revealed a connection with vitamin D level [39]), rs10877012 and rs4646537, did not reveal an increased risk either the proximal or the distal colon in this race [62]. 
Treatment of metastatic colorectal carcinoma is generally based on 5-flurouracil, which significantly improved the efficacy of treatment [63], however to optimize such treatment new drugs are still being searched. So far, only the influence of the rs 4588 polymorphism in VDBP (vitamin D binding protein) on the chosen treatment has been studied [63]. This may be extended to CYP27B1 in the near future.

The process of neoplasia within the large intestine is associated with the presence of low levels of 25(OH)D [64-66] and 1,25(OH $)_{2} \mathrm{D}[56,67]$. In addition to malignant neoplasms, the effect of rs4646536 polymorphism on colorectal adenoma was also investigated, however without success, as it did not affect either $1,25(\mathrm{OH})_{2} \mathrm{D}$ or $25(\mathrm{OH}) \mathrm{D}$ levels in the blood [68]. Other polymorphisms, such as rs28934604, rs58915677, and rs2229103, were discarded on account of the high monomorphism (most probably due to the suspicion of the pathogenic effect of variation), while rs10877012 (whose effect of vitamin D level in the blood was proven) was not taken into account due to the low MAF value [68].

\subsection{Prostate Cancer}

After the large intestine, the prostate is the next place where calcitriol is synthesized to satisfy the body's own needs [69].

In vitro, vitamin $\mathrm{D}$ affects human prostate cells by acting as a proliferation inhibitory factor [70]. Increased level of CYP27B1 expression is characteristic for the initial stage of malignant tumors, acting as an inhibitor of the progression of the disease [71,72]. However, other sources report that this phenomenon does not occur when it comes to prostate cancer [70]. This is explained by epigenetic mechanisms, so genetic variability will not impact to a large extend [73]. With the circulating 25(OH)D levels taken into account, the results were inconsistent. Some studies indicated that the level of this molecule diminishes the mortality associated with prostate cancer [74], while another did not find such an association [75], and yet another article found a link with tumor lethality [69].

The study of five polymorphisms within CYP27B1, namely rs1048691, rs4646537, rs703842, rs8176345, and rs10877013, did not show an increased risk of developing this cancer in any of the genotypes [76]. The results were obtained basing on the level of $25(\mathrm{OH}) \mathrm{D}$ and $1,25(\mathrm{OH})_{2} \mathrm{D}$ in serum [76]. Considerations about subsequent polymorphisms yielded results in only one case. For rs3782130, which is evolutionarily non-conserved and located in the $3^{\prime} \mathrm{UTR}$, the risk of mortality resulting from prostate cancer was reduced, while rs 4646537 did not give such results [71]. However, after repeated comparisons, rs3782130 did not show significance [71]. Interestingly, this polymorphism, along with five others within VDR or CYP24A1, was included in the SNP panel, which together with the clinical predictors strengthened the sensitivity of the test for 10-year prostate cancer-specific mortality from $91.4 \%$ to $94.3 \%$ (OR: $2.9,95 \%$ CI: $4.0 \%, 15.5 \%, p=0.2$ ) [71].

None of the three examined SNPs (rs10877012, rs8176345, and rs1048691) showed an increased risk of lethal prostate cancer [69].

Further research showed that among African Americans and older men of other races, the prostate cancer mortality rate is increasing because of the amount lowered of absorbed UV waves through the skin [77]. Among the African American representatives, the level of circulating 25(OH)D was two times lower compared to controls [78], which may be suspected to result in a lower protective effect against cancer [79]. Prostate cancer is known to be more common among African Americans [80], partially due to their socio-economic status [81]. A study of this polymorphism group containing rs4646537, rs3782130, rs10877012, and rs703842 did not reveal any association with tumor development [79]. From the group of rs1048691, rs4646537, rs4646536, rs8176345, rs10877012, and rs703842, it was found that rs 8176345 was among the 12 most common SNPs in Caucasians and African Americans, which showed statistical significance in this set of SNPs [82]. When investigating the interaction, simultaneously with the SNPs among CYP17, CYP19, CYP24A1, and CYP1B1 (rs10012, rs17115144, rs1048691, rs11636639, and rs3751592), this polymorphism showed a slight interaction in increasing the risk of prostate cancer development (permutation $p=0.04, \mathrm{CVC}$ (cross-validation consistency), 10/10; testing accuracy, 0.60) in African Americans [82]. 
In general, the association of three variables, the occurrence of a SNP within CYP27B1 (rs10877012, rs8176345, rs1048691), together with the level of circulating 25(OH)D did not show any relation to the mortality rate among those suffering from cancer [83]. The study of $25(\mathrm{OH}) \mathrm{D}$ levels and the correlation with the level of cancer mortality may not reflect the real situation in the prostate, because it is CYP27B1 that determines the bioavailability of the active metabolite of vitamin D [83]. Nevertheless, clinical trials have shown that vitamin D supplementation increased its circulating level, as well as the prostate tissue level [84].

These papers differ greatly in the reported levels of circulating vitamin D and the effect of a particular SNP. A possible explanation could be the differences between the study groups. Vitamin D can positively affect the population in which the PSA (prostate-specific antigen) is monitored with the disease at an early stage and provide therapeutic possibilities among other populations with advanced stages of cancer and restricted therapeutic possibilities [83].

\subsection{Breast Cancer}

The breast tissue is the next place where the CYP27B1 enzyme is present, and thus also the next place where conversion to calcitriol occurs [85]. The results indicate a positive correlation between longer exposure to the sun and reduced breast cancer mortality [86,87], whereas the collected data indicate mixed results when it comes to the effects of diet or supplementation [88,89]. The higher circulating level of $25(\mathrm{OH}) \mathrm{D}$ (i.e., above $38.0 \mathrm{ng} / \mathrm{mL}$ ) in blood reduced the risk of cancer development over the next five years ( $\mathrm{HR}=0.79 ; \mathrm{CI}: 0.63-0.98)$ [90]. Epidemiological studies indicated a positive effect for women with postmenopausal cancers.

The polymorphism rs 4646537 was excluded because the MAF was below 5\% [91]. The polymorphisms that were selected for this study appeared in earlier papers as factors influencing the occurrence of breast cancer [92]. The polymorphism rs10877012 in another study was taken into account, as only polymorphisms with MAF below two percent were excluded; a study within this polymorphism showed an interaction with 25(OH)D levels in relation to breast cancer development [90]. As the authors point out, this gene may play a role in the prevention of cancer in individual cases, depending on the amount of UV-B radiation and the content of vitamin D in the diet [85]. The study conducted in the Swedish population showed no effect of the selected polymorphism within CYP27B1 (rs4646537) on risk of cancer, as well as no effect of any SNP within the VDR, CYP24A1, RXRA (retinoid X receptor alpha), GC/VDBP, 7-dehydrocholesterol reductase (DHCR7), and CYP2R1 genes (112 SNPs in total) [93].

Two facts need to be considered: about $90 \%$ of vitamin D comes from biosynthesis in the body [94] and decreased levels in the case of dark pigmentation drove attention to investigating the occurrence of breast cancer in African Americans. Women with African American roots are at a higher risk of developing breast cancer at a younger age, which will be characterized by greater malignancy. This might be based on the negative status of estrogen receptors or lack of expression of estrogen and progesterone basal receptors $[95,96]$. The research showed that among African Americans, the level of 25(OH)D was generally lower. The next CYP27B1 study did not show an increased risk of breast cancer, even after differentiating the neoplasms in those with and without ER expression [97]. This article pointed out that other genes might have more frequent variations typical of Africans, so compiling a low level of 25(OH)D and a particular genotype can predispose people to the development of a specific type of cancer [97].

Primary stage breast cancer is widely treated with third generation aromatase inhibitors (AI) [98], however about a quarter of such patients develop AI-related arthralgia [99], which often terminates the course of therapy [100]. The mechanism of this undesirable effect is not fully understood. One of the suggested reasons is a deficiency of vitamin $\mathrm{D}$, which is very common in postmenopausal women with this cancer [101]. One study examined whether polymorphisms in CYP27B1 (rs10877012 and rs4646536) contribute to this side effect of the therapy [102]. Both SNPs showed a relationship with the increase in pain at three months after the end of therapy $(p<0.05)$ but they did not act in correcting the false discovery [102]. The interaction of the polymorphism rs3636536 within the VDR due to the 
functional relationship at 3 months after ending the therapy turned out to be borderline significant $(p=0.06)$, while the correlation of pain intensity in rs4646536 with the genotype CC in rs11568820 $(V D R)$ proved to be significant $(p=0.02)$ [102]. Subsequent association of the rs4646536 gene variant occurred at rs6163 in CYP17A1 ( $p=0.01)$, and the subsequent assessment of the intensity of pain with the genotype CC in rs6163 proved to be significant for both at $3(p=0.0006)$ and $12(p=0.003)$ months after ending treatment [102]. Having four adverse alleles within CYP27B1 and CYP17A1 increased the risk of AI-related arthralgia five-fold over a 12 months period [102]. In this study, no significant difference in $25(\mathrm{OH}) \mathrm{D}$ serum concentrations was noticed, but perhaps even normal circulating levels could not compensate for less functional enzymes in the vitamin D pathway [102].

\subsection{Lung Cancer}

Non-small cell lung cancer (NSCLC) is one of the most common malignancies, contributing to the largest number of deaths among all cancers annually [103]. For lung cancer, a reduced number of cases has been proven under the influence of increased exposure to UVB radiation, and consequently of synthesized vitamin D [104]. Interestingly, at the time of sufficient exposure to solar radiation (in summer and autumn), the number of deaths associated with this cancer decreases [105]. Circulating levels of 25(OH)D may be a prognostic factor for patients with early non-small cell lung cancer [106]. A Finnish female population-based study revealed a protective effect of elevated plasma $1,25(\mathrm{OH})_{2} \mathrm{D}$ levels on the development of lung cancer below the age of 50 [107], while a study in the male population showed reduced mortality at an earlier stage of cancer [108,109]. Another study demonstrated the highest CYP27B1 expression in alveolar macrophages that were present in advanced stages of the disease [110].

Cigarette smoke suppresses two important processes induced by vitamin D, namely NF- $k \mathrm{~B}$ (nuclear factor- $\mathrm{kB}$ ) signalling and the production of pro-inflammatory cytokines by activated epithelial cells [111].

The two polymorphisms rs10877012 and rs3782130 did not increase the risk of developing this type of cancer. When smokers and non-smokers were compared between themselves, correlating these polymorphisms with the plasma concentration of 25(OH)D did not show any statistical significance [112]. This is consistent with another GWAS, where there was no association between polymorphism in CYP27B1 and level of 25(OH)D [39]. However, regardless of the genotype, smokers had a significantly reduced level of 25(OH)D [112]. A study analyzing the same polymorphisms rs10877012 and rs3782130 showed a generally increased risk of lung cancer with the genotype GG at the rs3782130 polymorphic site (adjusted OR $=1.60,95 \%$ CI: 1.09-2.34) [113]. When the population was divided into smokers and non-smokers, results showed a nearly two-fold increase in the risk for smokers, where non-smokers did not show statistical significance $(\mathrm{OR}=1.91,95 \% \mathrm{CI}: 1.04-3.53)$ [113]. In addition to rs3782130, polymorphisms from the risk group include rs6068816 with homozygote CC (CYP24A1), rs4809957 with homozygote AA (CYP24A1), and rs7041 with TT homozygote (GC/VDBP). The study of multiple polymorphisms revealed that with one allele from these known risk polymorphisms, the chance of developing a cancer increased by 2.5 times on average, with two polymorphisms more than four times, and with three polymorphisms almost six times [113]. Rs3782130 is present within the $3^{\prime}$ end of the promoter and this location may influence the CYP27B1 gene transcription process, as was demonstrated by the lower gene transcription rate in tumor cells [113]. Elevated CYP27B1 expression could, thus, act as a prognostic factor for a higher survival rate in patients, especially for the older ones [113]. The explanation of a reduced survival when the GG genotype is present at the rs3782130 polymorphic site could be lower gene expression [113]. The rs3782130 polymorphism is considered to be the nuclear factor 1 binding site, which has a regulatory function in the transcription of many genes [114,115]. The occurrence of a particular genotype may, thus, have a different effect in the regulation of transcription [113]. 


\subsection{Pancreatic Cancer}

Over $90 \%$ of patients survive less than five years after diagnosis [116] and there is an urgent need to determine whether vitamin D plays a role in this cancer, which has a very high mortality rate. As in previously described malignancies, many studies suggest a reduced risk of pancreatic cancer with a high vitamin D status [117]. In areas with higher exposure to sunlight, and thus higher levels of vitamin $\mathrm{D}$ biosynthesis, fewer deaths occurred due to pancreatic cancer [118-120]. However, contradictory data can be found with regard to serum $25(\mathrm{OH})$ D levels, whereby in one study the elevated level indicated a higher risk of pancreatic cancer [121], whereas in another study lower or null risks occurred [122].

These studies included three polymorphisms within CYP27B1, of which rs10877013 was of greatest importance, while the others were rs703842 and rs1048691. However, none of them showed statistical significance in the risk of pancreatic cancer or in the $25(\mathrm{OH}) \mathrm{D}$ plasma concentration [117]. A Canadian population study within the of polymorphisms rs10877012, rs4646536, and rs703842 did not show an increased risk for the development of pancreatic cancer [116].

\subsection{Thyroid Cancer}

The thyroid is another CYP27B1 expression site [123]; however, no polymorphism within CYP27B1 has been studied for any type of thyroid cancer. The existing data are contradictory. The low level of vitamin $\mathrm{D}$ was initially associated with an increased risk of thyroid cancer development, however CYP27B1 expression is increased in the case of thyroid nodular cancer [124]. A study evaluating the expression of $V D R$ in thyroid cancer cells of different lines showed that VDR expression is at a different level, and a high level does not always provide a positive response to vitamin $D$ therapy [125]. Additionally, it could be assumed that the problem lies within CYP27B1 protein, but the study analyzed the level of CYP27B1 mRNA and showed that among cells more resistant to vitamin D therapy, this level was higher (but still it generally stayed at a lower level) [125]. The level was not elevated in response to therapy, so it was considered unsuitable for determining the sensitivity to activation [125]. This insensitivity to therapy was explained by down-regulation of $1-\alpha$-hydroxylase presence or activity [126]. One of the studies showed that patients with thyroid cancer have a reduced level of $1,25(\mathrm{OH})_{2} \mathrm{D}$ compared to healthy ones [127]. We have, as yet, no full understanding of what is happening to CYP27B1 in this type of tumor.

\subsection{Liver Cancer}

The contribution of the hepatitis $\mathrm{C}$ virus to the development of hepatocellular carcinoma (HCC) is undeniable [128], but the exact mechanism remains unknown. It was found that polymorphisms in genes encoding pro-inflammatory cytokines and ligands of growth factor receptors play an important role in this pathological process [129]. Even though an attempt to link polymorphisms in CYP27B1 SNPs rs4646536 and rs10877012 with the occurrence of this type of liver cancer in patients with chronic hepatitis $C$ treated with antiviral drugs for direct action showed a lack of statistical significance, these polymorphisms affect the development of HCC [130]. With genotypes CT and TT at the rs4646536 polymorphic site and genotype GG at the rs10877012 polymorphic site, there was no cancer incidence [130].

\subsection{Non-Hodgkin's Lymphoma}

Although it is a relatively frequent cancer disease, so far only a few risk factors for the development of this disease have been identified, one of which is the protective role of increased sun exposure [131], especially among younger study participants (13-21 years) [132]. However, there is not much data correlating $25(\mathrm{OH}) \mathrm{D}$ with the risk of disease, with one study showed no association [133]. Additionally, an analysis of germline variations within CYP27B1 rs4646537 and rs703842 did not show an increased risk for any of the variants [132]. 


\subsection{Other Diseases}

For rs10877012 (promoter, C > A), the association between the occurrence of specific alleles and an increased risk of Addison's autoimmune disease was found (for the $\mathrm{C}$ vs A alleles OR $=1.53,95 \% \mathrm{Cl}$ $1.07-2.19, p=0.02)[16,134]$, but simultaneously a reduced susceptibility to development of full-blown hepatitis $\mathrm{C}$ occurred (the $\mathrm{C}$ allele reduces the long-term antiviral response compared to the $\mathrm{A}$ allele, $p=0.02)[16,135]$. If rs4646536 is present in intron 6, the homozygote TT predestines to developing type I diabetes (OR: 2.14, 95\% CI: 1.07-1.36, $p=0.01$ ) compared to the CC homozygote (the authors highlight the case of linkage disequilibrium (LD) in rs10877012) [16,136]. The same polymorphism plays a role in the development of congestive heart failure in patients with hypertension and with mainly European roots [16,137]. Having the AC genotype at the rs4646537 polymorphic site and having mainly European ancestors reduces the risk of hypertension in the future [16,137].

\subsection{Multiple Sclerosis (MS)}

The autoimmune background of multiple sclerosis indicates a potentially low level of vitamin D as the main environmental factor affecting the etiopathogenesis of the disease [138]. This hypothesis was based on data on the inverse correlation between the occurrence of MS and the amount of exposure to UVB radiation $[139,140]$. Laboratory tests on a mouse model with experimental encephalomyelitis (MS model) have shown that vitamin D [141] is vital for the development of this pathology, however one of the components of effective treatment therapy was $1,25(\mathrm{OH})_{2} \mathrm{D}$ [142]. The study of the three different polymorphisms (rs118204009, rs118204011, and rs118204012) occurring within CYP27B1 in patients with multiple sclerosis showed that all were carriers of wild alleles [143] and none of the rare variants were found [143]. In in vitro studies, it was previously demonstrated that all three rare genetic variations within these SNPs lead to a loss of enzyme function and lowering of the level of the active metabolite of vitamin D [143]. In another study, rs118204009 was indicated as a polymorphism associated with the occurrence of MS [144], while in another study due to the very rare occurrence of this polymorphism, it was not confirmed by the lack of people with this rare variant [145]. A meta-analysis focusing only on rs703842 showed that the C allele significantly reduced the risk of multiple sclerosis in Caucasians [146].

\subsection{Vitamin-D-Dependent Rickets Type 1}

Different types of mutations within the CYP27B1 gene, such as sense-change mutations, insertions, and deletions, lead to rats associated with vitamin-D-dependent rickets type 1, which is a rare autosomal recessive disease [147]. Of these mutations, point mutations have also been identified. Genotyping of two young patients diagnosed with this disease showed that they had two new single nucleotide mutations in the CYP27B1 gene, marked as H441Y and R459L. This study showed that the first one minimally reduced the activity of the enzyme, while the second mutation reduced it dramatically [148]. The effect of R459L was to prevent CYP27B1 from interacting with adrenodoxin by creating a sulfide bridge, while H441Y inhibited the formation of hydrogen bonds with the same protein [148]. Another study showed a new c.1215 T>C (p.R379R) point variance at the very end of exon 7 in one of seven patients with rickets, which did not change the amino acid in the resulting protein. It is not known whether it affects the splicing process [149]. In the future, newly identified genetic variations may appear in other studies and in the dbSNP (Single Nucleotide Polymorphism Database), with a note that they are associated with the development of this type of the rickets.

\subsection{Oral Lichen Planus}

Oral lichen planus is a disease of unknown etiology, the course of which is characterized by inflammation of the oral mucosa [150]. It is considered to be a cancerous change due to some individuals developing cancer [151]. Due to this characteristic and the combination with the effect of inhibiting carcinogenesis through vitamin D, it is worth looking at the influence of SNP on the 
etiopathogenesis of this disease. Only one polymorphism rs4646536 was tested within CYP27B1 and there was no modification of the risk of lichen at any of the genotypes, but this polymorphism was associated with having a denture or artificial jaw [152]. Analysis of the multiloci interactions showed that the model where the polymorphism rs4646536 was present, as well as the polymorphisms in CYP24A1 (rs22962410), VDR (rs4516035 and rs2228570), and MTHFR (rs1801133), showed the best testing balancing accuracy and cross-validation consistency [152]. The obtained results of the lack of association of SNP in CYP27B1 are consistent with those obtained in the study of the risk of developing oral cancer [153].

\section{Conclusions}

The process of carcinogenesis is an extremely complex process that is influenced by numerous genetic and environmental factors. It should be noted that the largest impact of the level of $25(\mathrm{OH}) \mathrm{D}$ does not come from genetic factors, but from diet and exposure to sunlight only [154]. If there is a correlation between SNPs and a specific cancer, it can only indicate a moderate risk of disease. The greatest effect of polymorphisms was observed in the case of colon cancer. When it comes to the prostate, there was only one polymorphism rs8176345 noticed in the group of African Americans. In breast cancer, a relationship was observed at rs10877012, whereas in some cases rs4646536 contributed to the occurrence of side effects during the treatment of the pathology. The risk of small-cell lung cancer underwent modifications in the case of rs3782130. The two other polymorphisms rs10877012 and rs4646536 have an impact on the development of hepatocellular carcinoma in HCV patients. There was no evidence of dependence for pancreas, thyroid, or non-Hodgkin's lymphoma. The important role of vitamin $\mathrm{D}$ in the ethiopathogenesis of multiple sclerosis and vitamin-D-dependent rickets type 1 was based on CYP27B1 polymorphisms. A summary of the role of polymorphisms in CYP27B1 gene in the occurrence of diseases is provided in Table 1.

Table 1. CYP27B1 gene polymorphisms (SNPs) and their roles in disease occurrence.

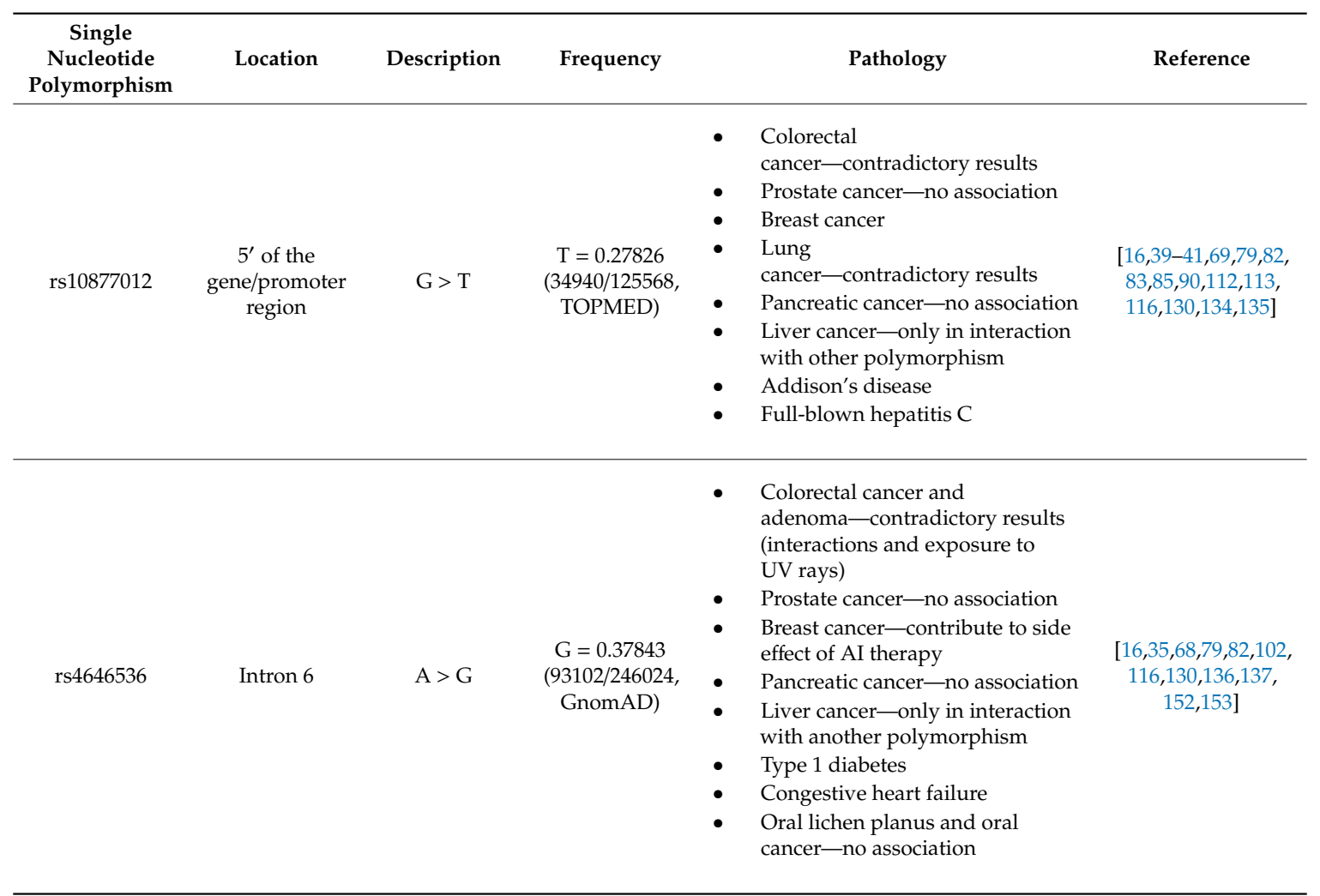


Table 1. Cont

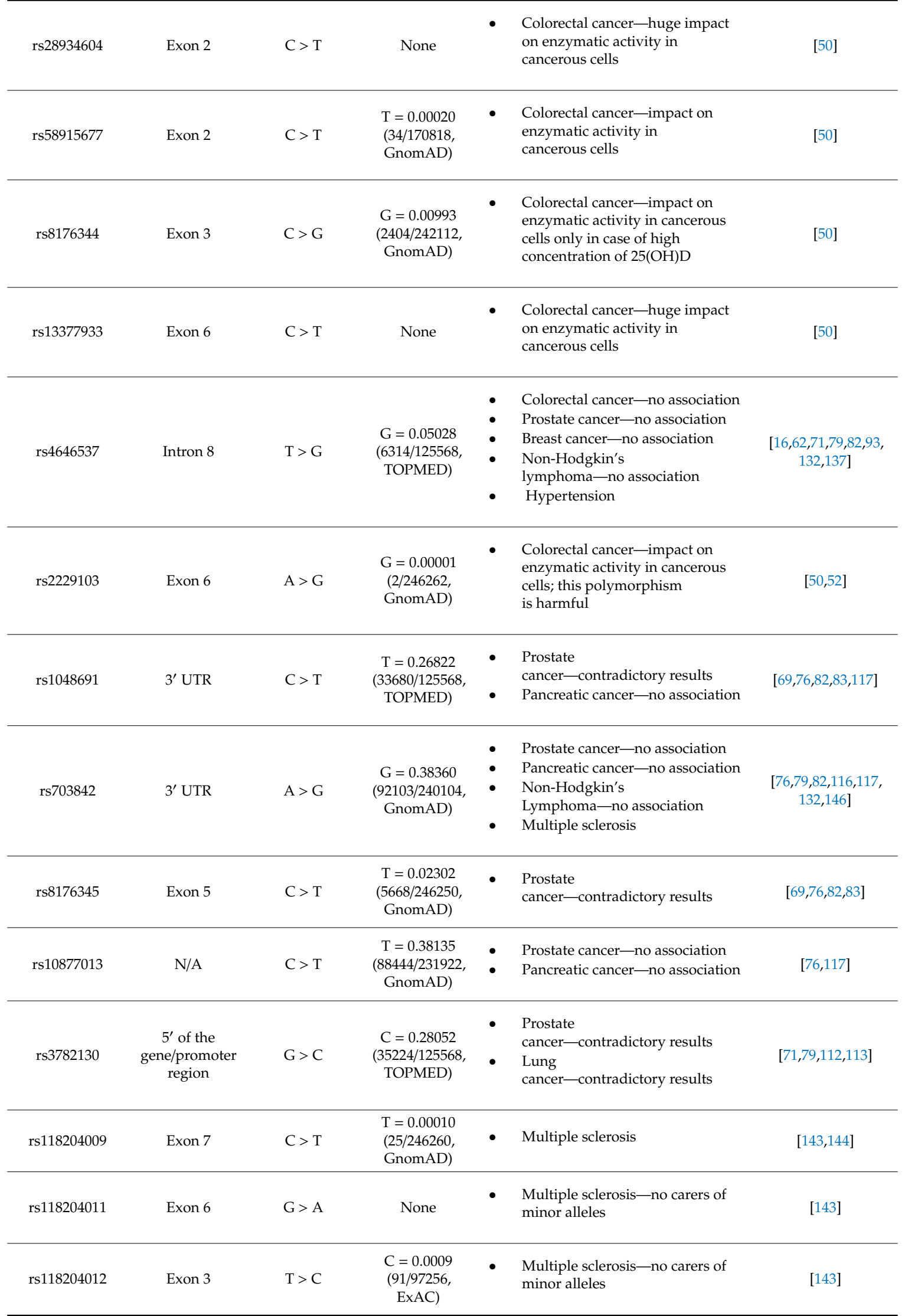

A, adenine; T, thymine; C, cytosine; G, guanine; TOPMED, Trans-Omics for Precision Medicine; GnomAD, Genome Aggregation Database; ExAC, Exome Aggregation Consortium; UV, ultraviolet; AI, aromatase inhibitor. 
Genotyping of SNPs is an easy, accessible procedure; moreover, it is sufficient to perform it once in a lifetime. Based on the gathered pieces of information, it would be possible to create a panel of SNPS in CYP27B1 that are associated with malignancies and other chronic diseases, and as a consequence, identify the group with the highest risk of incidence of these diseases. It could thereby contribute to prevention or diagnosis of these illnesses at an early stage.

Author Contributions: M.L. Writing, Original Draft Preparation; J.S. Writing, Review \& Editing; E.K. Writing, Review \& Editing, E.F. Original Draft Preparation, H.F.J.S. Writing, Review \& Editing, R.G. Original Draft Preparation; A.C. Conceptualization, Writing, Review \& Editing. All authors have read and agreed to the published version of the manuscript.

Funding: This research received no external funding.

Conflicts of Interest: The authors declare no conflict of interest.

\section{References}

1. Feldman, D.; Krishnan, A.V.; Swami, S.; Giovannucci, E.; Feldman, B.J. The role of vitamin D in reducing cancer risk and progression. Nat. Rev. Cancer 2014, 14, 342-357. [CrossRef] [PubMed]

2. Adams, J.S.; Rafison, B.; Witzel, S.; Reyes, R.E.; Shieh, A.; Chun, R.; Zavala, K.; Hewison, M.; Liu, P.T. Regulation of extrarenal CYP27B1-hydroxylase. J. Steroid Biochem. Mol. Biol. 2014, 144, 22-27. [CrossRef] [PubMed]

3. Abe, E.; Miyaura, C.; Sakagami, H.; Takeda, M.; Konno, K.; Yamazaki, T.; Yoshiki, S.; Suda, T. Differentiation of mouse myeloid leukemia cells induced by 1 alpha,25-dihydroxyvitamin D3. Proc. Natl. Acad. Sci. USA 1981, 78, 4990-4994. [CrossRef] [PubMed]

4. Barbour, G.L.; Coburn, J.W.; Slatopolsky, E.; Norman, A.W.; Horst, R.L. Hypercalcemia in an anephric patient with sarcoidosis: Evidence for extrarenal generation of 1,25-dihydroxyvitamin D. N. Engl. J. Med. 1981, 305, 440-443. [CrossRef] [PubMed]

5. Provvedini, D.M.; Tsoukas, C.D.; Deftos, L.J.; Manolagas, S.C. 1,25-dihydroxyvitamin D3 receptors in human leukocytes. Science 1983, 221, 1181-1183. [CrossRef]

6. Colston, K.; Colston, M.J.; Feldman, D. 1,25-dihydroxyvitamin D3 and malignant melanoma: The presence of receptors and inhibition of cell growth in culture. Endocrinology 1981, 108, 1083-1086. [CrossRef]

7. Pereira, F.; Larriba, M.J.; Munoz, A. Vitamin D and colon cancer. Endocr. Relat. Cancer 2012, 19, R51-R71. [CrossRef]

8. Swami, S.; Krishnan, A.V.; Wang, J.Y.; Jensen, K.; Peng, L.; Albertelli, M.A.; Feldman, D. Inhibitory effects of calcitriol on the growth of MCF-7 breast cancer xenografts in nude mice: Selective modulation of aromatase expression in vivo. Horm. Cancer 2011, 2, 190-202. [CrossRef]

9. Swami, S.; Krishnan, A.V.; Peng, L.; Lundqvist, J.; Feldman, D. Transrepression of the estrogen receptor promoter by calcitriol in human breast cancer cells via two negative vitamin D response elements. Endocr. Relat. Cancer 2013, 20, 565-577. [CrossRef]

10. Krishnan, A.V.; Shinghal, R.; Raghavachari, N.; Brooks, J.D.; Peehl, D.M.; Feldman, D. Analysis of vitamin D-regulated gene expression in LNCaP human prostate cancer cells using cDNA microarrays. Prostate 2004, 59, 243-251. [CrossRef]

11. Zhao, X.Y.; Peehl, D.M.; Navone, N.M.; Feldman, D. $1 \alpha, 25$-dihydroxyvitamin $\mathrm{D}_{3}$ inhibits prostate cancer cell growth by androgen-dependent and androgen-independent mechanisms. Endocrinology 2000, 141, 2548-2556. [CrossRef] [PubMed]

12. Tuohimaa, P.; Lyakhovich, A.; Aksenov, N.; Pennanen, P.; Syvälä, H.; Lou, Y.R.; Ahonen, M.; Hasan, T.; Pasanen, P.; Bläuer, M.; et al. Vitamin D and prostate cancer. J. Steroid Biochem. Mol. Biol. 2001, 76, 125-134. [CrossRef]

13. Jenkinson, C. The vitamin D metabolome: An update on analysis and function. Cell Biochem. Funct. 2019, 37, 408-423. [CrossRef] [PubMed]

14. Morrison, N.A.; Qi, J.C.; Tokita, A.; Kelly, P.J.; Crofts, L.; Nguyen, T.V.; Sambrook, P.N.; Eisman, J.A. Prediction of bone density from vitamin D receptor alleles. Nature 1994, 367, 284-287. [CrossRef] [PubMed] 
15. Morrison, N.A.; Yeoman, R.; Kelly, P.J.; Eisman, J.A. Contribution of trans-acting factor alleles to normal physiological variability: Vitamin D receptor gene polymorphism and circulating osteocalcin. Proc. Natl. Acad. Sci. USA 1992, 89, 6665-6669. [CrossRef] [PubMed]

16. Jolliffe, D.A.; Walton, R.T.; Griffiths, C.J.; Martineau, A.R. Single nucleotide polymorphisms in the vitamin D pathway associating with circulating concentrations of vitamin D metabolites and non-skeletal health outcomes: Review of genetic association studies. J. Steroid Biochem. Mol. Biol. 2016, 164, 18-29. [CrossRef]

17. Deeb, K.K.; Trump, D.L.; Johnson, C.S. Vitamin D signalling pathways in cancer: Potential for anticancer therapeutics. Nat. Rev. Cancer 2007, 7, 684-700. [CrossRef]

18. Holick, M.F. Vitamin D deficiency. N. Engl. J. Med. 2007, 357, 266-281. [CrossRef]

19. Millen, A.E.; Bodnar, L.M. Vitamin D assessment in population-based studies: A review of the issues. Am. J. Clin. Nutr. 2008, 87, 1102S-1105S. [CrossRef]

20. Muindi, J.R.; Adjei, A.A.; Wu, Z.R.; Olson, I.; Huang, H.; Groman, A.; Tian, L.; Singh, P.K.; Sucheston, L.E.; Johnson, C.S.; et al. Serum Vitamin D metabolites in colorectal cancer patients receiving cholecalciferol supplementation: Correlation with polymorphisms in the vitamin D genes. Horm. Cancer 2012, 4, 242-250. [CrossRef]

21. Fu, G.K.; Portale, A.A.; Miller, W.L. Complete structure of the human gene for the vitamin D 1-alpha-hydroxylase, P450cl-alpha. DNA Cell Biol. 1997, 16, 1499-1507. [CrossRef] [PubMed]

22. Kitanaka, S.; Takeyama, K.; Murayama, A.; Sato, T.; Okumura, K.; Nogami, M.; Hasegawa, Y.; Niimi, H.; Yanagisawa, J.; Tanaka, T.; et al. Inactivating mutations in the 25-hydroxyvitamin D3 1alpha-hydroxylase gene in patients with pseudovitamin D-deficiency rickets. N. Engl. J. Med. 1998, 338, 653-661. [CrossRef] [PubMed]

23. Kong, X.F.; Zhu, X.H.; Pei, Y.L.; Jackson, D.M.; Holick, M.F. Molecular cloning, characterization, and promoter analysis of the human 25-hydroxyvitamin D3-1alpha-hydroxylase gene. Proc. Natl. Acad. Sci. USA 1999, 96, 6988-6993. [CrossRef] [PubMed]

24. Kawashima, H.; Kurokawa, K. Unique hormonal regulation of vitamin D metabolism in the mammalian kidney. Miner. Electrolyte Metab. 1983, 9, 227-235. [PubMed]

25. Kawashima, H.; Torikai, S.; Kurokawa, K. Calcitonin selectively stimulates 25-hydroxyvitamin D3-1 alpha-hydroxylase in the proximal straight tubule of the rat kidney. Nature 1981, 291, 327-329. [CrossRef]

26. Adams, J.S.; Hewison, M. Extrarenal expression of the 25-hydroxyvitamin D-1-hydroxylase. Arch. Biochem. Biophys. 2012, 523, 95-102. [CrossRef]

27. Christakos, S.; DeLuca, H.F. Minireview: Vitamin D: Is there a role in extraskeletal health? Endocrinology 2011, 152, 2930-2936. [CrossRef]

28. Cross, H.S.; Petra Bareis, P.; Hofer, H.; Bischof, M.G.; Bajna, E.; Kriwanek, S.; Bonner, E.; Peterlik, M. 25 -Hydroxyvitamin D3- $1 \alpha$-hydroxylase and vitamin D receptor gene expression in human colonic mucosa is elevated during early cancerogenesis. Steroids 2001, 66, 287-292. [CrossRef]

29. Grant, W.B.; Garland, C.F. A critical review of studies on vitamin D in relation to colorectal cancer. Nutr. Cancer 2004, 48, 115-123. [CrossRef]

30. Giovannucci, E. The epidemiology of vitamin D and colorectal cancer: Recent findings. Curr. Opin. Gastroenterol. 2006, 22, 24-29. [CrossRef]

31. Wactawski-Wende, J.; Kotchen, J.M.; Anderson, G.L.; Assaf, A.R.; Brunner, R.L.; O’Sullivan, M.J.; Margolis, K.L.; Ockene, J.K.; Phillips, L.; Women's Health Initiative Investigators; et al. Calcium plus vitamin D supplementation and the risk of colorectal cancer. N. Engl. J. Med. 2006, 354, 684-696. [CrossRef] [PubMed]

32. Zhang, X.; Giovannucci, E. Calcium, vitamin D and colorectal cancer chemoprevention. Best Pract. Res. Clin. Gastroenterol. 2011, 25, 485-494. [CrossRef] [PubMed]

33. Tangpricha, V.; Flanagan, J.N.; Whitlatch, L.W.; Tseng, C.C.; Chen, T.C.; Holt, P.R.; Lipkin, M.S.; Holick, M.F. 25-hydroxyvitamin D-1alpha-hydroxylase in normal and malignant colon tissue. Lancet 2001, 357, 1673-1674. [CrossRef]

34. Kállay, E.; Bises, G.; Bajna, E.; Bieglmayer, C.; Gerdenitsch, W.; Steffan, I.; Kato, S.; Armbrecht, H.J.; Cross, H.S. Colon-specific regulation of vitamin D hydroxylases - a possible approach for tumor prevention. Carcinogenesis 2005, 26, 1581-1589. [CrossRef] [PubMed] 
35. Dong, L.M.; Ulrich, C.M.; Hsu, L.; Duggan, D.J.; Benitez, D.S.; White, E.; Slattery, M.L.; Farin, F.M.; Makar, K.W.; Carlson, C.S.; et al. Vitamin D related genes, CYP24A1 and CYP27B1, and colon cancer risk. Cancer Epidemiol. Biomarkers Prev. 2009, 18, 2540-2548. [CrossRef] [PubMed]

36. Bises, G.; Kállay, E.; Weiland, T.; Wrba, F.; Wenzl, E.; Bonner, E.; Kriwanek, S.; Obrist, P.; Cross, H.S. 25-hydroxyvitamin D3-1alpha-hydroxylase expression in normal and malignant human colon. J. Histochem. Cytochem. 2004, 52, 985-989. [CrossRef] [PubMed]

37. Gacche, R.N. Compensatory angiogenesis and tumor refractoriness. Oncogenesis 2015, 4, e153. [CrossRef]

38. Moan, J.; Porojnicu, A.; Lagunova, Z.; Berg, J.P.; Dahlback, A. Colon cancer: Prognosis for different latitudes, age groups and seasons in Norway. J. Photochem. Photobiol. 2007, 89, 148-155. [CrossRef]

39. Wang, T.J.; Zhang, F.; Richards, J.B.; Kestenbaum, B.; van Meurs, J.B.; Berry, D.; Kiel, D.P.; Streeten, E.A.; Ohlsson, C.; Koller, D.L.; et al. Common genetic determinants of vitamin D insufficiency: A genome-wide association study. Lancet 2010, 376, 180-188. [CrossRef]

40. McGrath, J.J.; Saha, S.; Burne, T.H.; Eyles, D.W. A systematic review of the association between common single nucleotide polymorphisms and 25-hydroxyvitamin D concentrations. J. Steroid Biochem. Mol. Biol. 2010, 121, 471-477. [CrossRef]

41. Bu, F.X.; Armas, L.; Lappe, J.; Zhou, Y.; Gao, G.; Wang, H.W.; Recker, R.; Zhao, L.J. Comprehensive association analysis of nine candidate genes with serum 25-hydroxy vitamin D levels among healthy Caucasian subjects. Hum. Genet. 2010, 128, 549-556. [CrossRef] [PubMed]

42. Pettifor, J.M.; Bikle, D.D.; Cavaleros, M.; Zachen, D.; Kamdar, M.C.; Ross, F.P. Serum levels of free 1,25-dihydroxyvitamin D in vitamin D toxicity. Ann. Intern. Med. 1995, 122, 511-513. [CrossRef] [PubMed]

43. Cancer Genome Atlas Network. Comprehensive molecular characterization of human colon and rectal cancer. Nature 2012, 487, 330-337. [CrossRef] [PubMed]

44. McBain, A.J.; Macfarlane, G.T. Ecological and physiological studies on large intestinal bacteria in relation to production of hydrolytic and reductive enzymes involved in formation of genotoxic metabolites. J. Med. Microbiol. 1998, 47, 407-416. [CrossRef]

45. Lagergren, J.; Ye, W.; Ekbom, A. Intestinal cancer after cholecystectomy: Is bile involved in carcinogenesis? Gastroenterology 2001, 121, 542-547. [CrossRef]

46. Meguid, R.A.; Slidell, M.B.; Wolfgang, C.L.; Chang, D.C.; Ahuja, N. Is there a difference in survival between right - versus left-sided colon cancers? Ann. Surg. Oncol. 2008, 15, 2388-2394. [CrossRef]

47. Meggouh, F.; Lointier, P.; Pezet, D.; Saez, S. Evidence of 1,25-dihydroxyvitamin D3-receptors in human digestive mucosa and carcinoma tissue biopsies taken at different levels of the digestive tract, in 152 patients. J. Steroid Biochem. 1990, 36, 143-147. [CrossRef]

48. Suttie, S.A.; Shaikh, I.; Mullen, R.; Amin, A.I.; Daniel, T.; Yalamarthi, S. Outcome of right- and left-sided colonic and rectal cancer following surgical resection. Colorectal Dis. 2011, 13, 884-889. [CrossRef]

49. Hughes, T.A. Regulation of gene expression by alternative untranslated regions. Trends Genet. 2006, 22, 119-122. [CrossRef]

50. Jacobs, E.T.; Van Pelt, C.; Forster, R.E.; Zaidi, W.; Hibler, E.A.; Galligan, M.A.; Haussler, M.R.; Jurutka, P.W. CYP24A1 and CYP27B1 polymorphisms modulate vitamin D metabolism in colon cancer cells. Cancer Res. 2013, 73, 2563-2573. [CrossRef]

51. Meunier, B.; de Visser, S.P.; Shaik, S. Mechanism of oxidation reactions catalyzed by cytochrome p450 enzymes. Chem. Rev. 2004, 104, 3947-3980. [CrossRef] [PubMed]

52. Wang, L.L.; Li, Y.; Zhou, S.F. A bioinformatics approach for the phenotype prediction of nonsynonymous single nucleotide polymorphisms in human cytochromes P450. Drug Metab. Dispos. 2009, 37, 977-991. [CrossRef] [PubMed]

53. dbSNP. Available online: https://www.ncbi.nlm.nih.gov/snp/rs10877012 (accessed on 24 February 2020).

54. Chia, V.; Newcomb, P.A. Calcium and colorectal cancer: Some questions remain. Nutr. Rev. 2004, 62, 115-120. [CrossRef] [PubMed]

55. Dong, L.M.; Ulrich, C.M.; Hsu, L.; Duggan, D.J.; Benitez, D.S.; White, E.; Slattery, M.L.; Caan, B.J.; Potter, J.D.; Peters, U. Genetic variation in calcium-sensing receptor and risk for colon cancer. Cancer Epidemiol. Biomarkers Prev. 2008, 17, 2755-2765. [CrossRef]

56. Feskanich, D.; Ma, J.; Fuchs, C.S.; Kirkner, G.J.; Hankinson, S.E.; Hollis, B.W.; Giovannucci, E.L. Plasma vitamin D metabolites and risk of colorectal cancer in women. Cancer Epidemiol. Biomarkers Prev. 2004, 13, 1502-1508. 
57. Ma, Y.; Zhang, P.; Wang, F.; Yang, J.; Liu, Z.; Qin, H. Association between vitamin D and risk of colorectal cancer: A systematic review of prospective studies. J. Clin. Oncol. 2011, 29, 3775-3782. [CrossRef]

58. Wu, K.; Feskanich, D.; Fuchs, C.S.; Chan, A.T.; Willett, W.C.; Hollis, B.W.; Pollak, M.N.; Giovannucci, E. Interactions between plasma levels of 25-hydroxyvitamin D, insulin-like growth factor (IGF)-1 and C-peptide with risk of colorectal cancer. PLOS ONE 2011, 6, e28520. [CrossRef]

59. Hong, S.N.; Kim, J.H.; Choe, W.H.; Lee, S.Y.; Seol, D.C.; Moon, H.W.; Hur, M.; Yun, Y.M.; Sung, I.K.; Park, H.S.; et al. Circulating vitamin $\mathrm{D}$ and colorectal adenoma in asymptomatic average-risk individuals who underwent first screening colonoscopy: A case-control study. Dig. Dis. Sci. 2012, 57, 753-763. [CrossRef]

60. Giovannucci, E. Vitamin D and cancer incidence in the Harvard cohorts. Ann. Epidemiol. 2009, 19, 84-88. [CrossRef]

61. Kühn, T.; Kaaks, R.; Teucher, B.; Hirche, F.; Dierkes, J.; Weikert, C.; Katzke, V.; Boeing, H.; Stangl, G.I.; Buijsse, B. Dietary, lifestyle, and genetic determinants of vitamin D status: A cross-sectional analysis from the European Prospective Investigation into Cancer and Nutrition (EPIC)-Germany study. Eur. J. Nutr. 2013, 53, 731-741. [CrossRef]

62. Pibiri, F.; Kittles, R.; Sandler, R.S.; Keku, T.O.; Kupfer, S.S.; Xicola, R.M.; Llor, X.; Ellis, N.A. Genetic variation in vitamin D-related genes and risk of colorectal cancer in African Americans. Cancer Causes Control 2014, 25, 561-570. [CrossRef] [PubMed]

63. Berger, M.D.; Lenz, H.J. The safety of monoclonal antibodies for treatment of colorectal cancer. Expert Opin. Drug. Saf. 2016, 15, 799-808. [CrossRef] [PubMed]

64. Yin, L.; Grandi, N.; Raum, E.; Haug, U.; Arndt, V.; Brenner, H. Meta-analysis: Serum vitamin D and colorectal adenoma risk. Prev. Med. 2011, 53, 10-16. [CrossRef]

65. Gandini, S.; Boniol, M.; Haukka, J.; Byrnes, G.; Cox, B.; Sneyd, M.J.; Mullie, P.; Autier, P. Meta-analysis of observational studies of serum 25-hydroxyvitamin D levels and colorectal, breast and prostate cancer and colorectal adenoma. Int. J. Cancer 2011, 128, 1414-1424. [CrossRef] [PubMed]

66. Wei, M.Y.; Garland, C.F.; Gorham, E.D.; Mohr, S.B.; Giovannucci, E. Vitamin D and prevention of colorectal adenoma: A meta-analysis. Cancer Epidemiol. Biomark. Prev. 2008, 17, 2958-2969. [CrossRef] [PubMed]

67. Hibler, E.A.; Sardo Molmenti, C.L.; Lance, P.; Jurutka, P.W.; Jacobs, E.T. Associations between circulating 1,25(OH)2D concentration and odds of metachronous colorectal adenoma. Cancer Causes Control 2014, 25, 809-817. [CrossRef]

68. Hibler, E.A.; Klimentidis, Y.C.; Jurutka, P.W.; Kohler, L.N.; Lance, P.; Roe, D.J.; Thompson, P.A.; Jacobs, E.T. CYP24A1 and CYP27B1 polymorphisms, concentrations of vitamin D metabolites, and odds of colorectal adenoma recurrence. Nutr. Cancer 2015, 67, 1131-1141. [CrossRef]

69. Shui, I.M.; Mucci, L.A.; Kraft, P.; Tamimi, R.M.; Lindstrom, S.; Penney, K.L.; Nimptsch, K.; Hollis, B.W.; Dupre, N.; Platz, E.A.; et al. Vitamin D-related genetic variation, plasma vitamin D, and risk of lethal prostate cancer: A prospective nested case-control study. J. Natl. Cancer Inst. 2012, 104, 690-699. [CrossRef]

70. Bikle, D.D.; Patzek, S.; Wang, Y. Physiologic and pathophysiologic roles of extra renal CYP27B1: Case report and review. Bone Rep. 2018, 8, 255-267. [CrossRef]

71. Holt, S.K.; Kwon, E.M.; Koopmeiners, J.S.; Lin, D.W.; Feng, Z.; Ostrander, E.A.; Peters, U.; Stanford, J.L. Vitamin D pathway gene variants and prostate cancer prognosis. Prostate 2010, 70, 1448-1460. [CrossRef]

72. Albanes, D.; Mondul, A.M.; Yu, K.; Parisi, D.; Horst, R.L.; Virtamo, J.; Weinstein, S.J. Serum 25-hydroxy vitamin D and prostate cancer risk in a large nested case-control study. Cancer Epidemiol. Biomark. Prev. 2011, 20, 1850-1860. [CrossRef] [PubMed]

73. Chen, T.C.; Wang, L.; Whitlatch, L.W.; Flanagan, J.N.; Holick, M.F. Prostatic 25-hydroxyvitamin D-1alphahydroxylase and its implication in prostate cancer. J. Cell Biochem. 2003, 88, 315-322. [CrossRef] [PubMed]

74. Tretli, S.; Hernes, E.; Berg, J.P.; Hestvik, U.E.; Robsahm, T.E. Association between serum 25(OH)D and death from prostate cancer. Br. J. Cancer 2009, 100, 450-454. [CrossRef] [PubMed]

75. Fang, F.; Kasperzyk, J.L.; Shui, I.; Hendrickson, W.; Hollis, B.W.; Fall, K.; Ma, J.; Gaziano, J.M.; Stampfer, M.J.; Mucci, L.A.; et al. Prediagnostic plasma vitamin D metabolites and mortality among patients with prostate cancer. PLOS ONE 2011, 6, e18625. [CrossRef]

76. Ahn, J.; Albanes, D.; Berndt, S.I.; Peters, U.; Chatterjee, N.; Freedman, N.D.; Abnet, C.C.; Huang, W.Y.; Kibel, A.S.; Crawford, E.D.; et al. Vitamin D-related genes, serum vitamin D concentrations and prostate cancer risk. Carcinogenesis 2009, 30, 769-776. [CrossRef] 
77. Johnson, M.A.; Davey, A.; Park, S.; Hausman, D.B.; Poon, L.W.; Georgia Centenarian Study. Age race and season predict vitamin D status in African American and white octogenarians and centenarians. J. Nutr. Health Aging 2008, 12, 690-695.

78. Roff, A.; Wilson, R.T. A novel SNP in a vitamin D response element of the CYP24A1 promoter reduces protein binding, transactivation, and gene expression. J. Steroid Biochem. Mol. Biol. 2008, 112, 47-54. [CrossRef]

79. Bonilla, C.; Hooker, S.; Mason, T.; Bock, C.H.; Kittles, R.A. Prostate cancer susceptibility loci identified on chromosome 12 in African Americans. PLoS ONE 2011, 6, e16044. [CrossRef]

80. Reddy, S.; Shapiro, M.; Morton, R.; Brawley, O.W. Prostate cancer in black and white Americans. Cancer Metastasis Rev. 2003, 22, 83-86. [CrossRef]

81. Whitman, E.J.; Pomerantz, M.; Chen, Y.; Chamberlin, M.M.; Furusato, B.; Gao, C.; Ali, A.; Ravindranath, L.; Dobi, A.; Sesterhenn, I.A.; et al. Prostate cancer risk allele specific for African descent associates with pathologic stage at prostatectomy. Cancer Epidemiol. Biomark. Prev. 2010, 19, 1-8. [CrossRef]

82. Beuten, J.; Gelfond, J.A.; Franke, J.L.; Weldon, K.S.; Crandall, A.C.; Johnson-Pais, T.L.; Thompson, I.M.; Leach, R.J. Single and multigenic analysis of the association between variants in 12 steroid hormone metabolism genes and risk of prostate cancer. Cancer Epidemiol. Biomark. Prev. 2009, 18, 1869-1880. [CrossRef] [PubMed]

83. Shui, I.M.; Mondul, A.M.; Lindström, S.; Tsilidis, K.K.; Travis, R.C.; Gerke, T.; Albanes, D.; Mucci, L.A.; Giovannucci, E.; Kraft, P.; et al. Circulating vitamin D, vitamin D-related genetic variation, and risk of fatal prostate cancer in the National Cancer Institute Breast and Prostate Cancer Cohort Consortium. Cancer 2015, 121, 1949-1956. [CrossRef] [PubMed]

84. Wagner, D.; Trudel, D.; Van der Kwast, T.; Nonn, L.; Giangreco, A.A.; Li, D.; Dias, A.; Cardoza, M.; Laszlo, S.; Hersey, K.; et al. Randomized clinical trial of vitamin D3 doses on prostatic vitamin D metabolite levels and ki67 labeling in prostate cancer patients. J. Clin. Endocrinol. Metab. 2013, 98, 1498-1507. [CrossRef] [PubMed]

85. O'Brien, K.M.; Sandler, D.P.; Kinyamu, H.K.; Taylor, J.A.; Weinberg, C.R. Single-nucleotide polymorphisms in vitamin D-related genes may modify vitamin D-breast cancer associations. Cancer Epidemiol. Biomark. Prev. 2017, 26, 1761-1771. [CrossRef] [PubMed]

86. Yang, L.; Veierød, M.B.; Löf, M.; Sandin, S.; Adami, H.O.; Weiderpass, E. Prospective study of UV exposure and cancer incidence among Swedish women. Cancer Epidemiol. Biomark. Prev. 2011, 20, 1358-1367. [CrossRef]

87. Anderson, L.N.; Cotterchio, M.; Kirsh, V.A.; Knight, J.A. Ultraviolet sunlight exposure during adolescence and adulthood and breast cancer risk: A population-based case-control study among Ontario women. Am. J. Epidemiol. 2011, 174, 293-304. [CrossRef]

88. Rossi, M.; McLaughlin, J.K.; Lagiou, P.; Bosetti, C.; Talamini, R.; Lipworth, L.; Giacosa, A.; Montella, M.; Franceschi, S.; Negri, E.; et al. Vitamin D intake and breast cancer risk: A case-control study in Italy. Ann. Oncol. 2009, 20, 374-378. [CrossRef]

89. McCullough, M.L.; Rodriguez, C.; Diver, W.R.; Feigelson, H.S.; Stevens, V.L.; Thun, M.J.; Calle, E.E. Dairy, calcium, and vitamin D intake and postmenopausal breast cancer risk in the Cancer Prevention Study II Nutrition Cohort. Cancer Epidemiol. Biomark. Prev. 2005, 14, 2898-2904. [CrossRef]

90. O'Brien, K.M.; Sandler, D.P.; Taylor, J.A.; Weinberg, C.R. Serum vitamin D and risk of breast cancer within five years. Environ. Health Perspect. 2017, 125, 077004. [CrossRef]

91. Reimers, L.L.; Crew, K.D.; Bradshaw, P.T.; Santella, R.M.; Steck, S.E.; Sirosh, I.; Terry, M.B.; Hershman, D.L.; Shane, E.; Cremers, S.; et al. Vitamin D-related gene polymorphisms, plasma 25-hydroxyvitamin D, and breast cancer risk. Cancer Causes Control 2015, 26, 187-203. [CrossRef]

92. McCullough, M.L.; Bostick, R.M.; Mayo, T.L. Vitamin D gene pathway polymorphisms and risk of colorectal, breast, and prostate cancer. Annu. Rev. Nutr. 2009, 29, 111-132. [CrossRef] [PubMed]

93. Clendenen, T.V.; Ge, W.; Koenig, K.L.; Axelsson, T.; Liu, M.; Afanasyeva, Y.; Andersson, A.; Arslan, A.A.; Chen, Y.; Hallmans, G.; et al. Genetic polymorphisms in vitamin D metabolism and signaling genes and risk of breast cancer: A nested case-control study. PLOS ONE 2015, 10, e0140478. [CrossRef] [PubMed]

94. Clemens, T.L.; Adams, J.S.; Henderson, S.L.; Holick, M.F. Increased skin pigment reduces the capacity of skin to synthesise vitamin D3. Lancet 1982, 1, 74-76. [CrossRef]

95. Amend, K.; Hicks, D.; Ambrosone, C.B. Breast cancer in African-American women: Differences in tumor biology from European-American women. Cancer Res. 2006, 66, 8327-8330. [CrossRef] 
96. Ooi, L.L.; Zhou, H.; Kalak, R.; Zheng, Y.; Conigrave, A.D.; Seibel, M.J.; Dunstan, C.R. Vitamin D deficiency promotes human breast cancer growth in a murine model of bone metastasis. Cancer Res. 2010, 70, 1835-1844. [CrossRef]

97. Yao, S.; Zirpoli, G.; Bovbjerg, D.H.; Jandorf, L.; Hong, C.C.; Zhao, H.; Sucheston, L.E.; Tang, L.; Roberts, M.; Ciupak, G.; et al. Variants in the vitamin D pathway, serum levels of vitamin D, and estrogen receptor negative breast cancer among African-American women: A case-control study. Breast Cancer Res. 2012, 14, R58. [CrossRef]

98. Kudachadkar, R.; O'Regan, R.M. Aromatase inhibitors as adjuvant therapy for postmenopausal patients with early stage breast Cancer. CA Cancer J. Clin. 2005, 55, 145-163. [CrossRef]

99. Henry, N.L.; Azzouz, F.; Desta, Z.; Li, L.; Nguyen, A.T.; Lemler, S.; Hayden, J.; Tarpinian, K.; Yakim, E.; Flockhart, D.A.; et al. Predictors of aromatase inhibitor discontinuation as a result of treatment-emergent symptoms in early-stage breast cancer. J. Clin. Oncol. 2012, 30, 936-942. [CrossRef]

100. Crew, K.D.; Greenlee, H.; Capodice, J.; Raptis, G.; Brafman, L.; Fuentes, D.; Sierra, A.; Hershman, D.L. Prevalence of joint symptoms in postmenopausal women taking aromatase inhibitors for early-stage breast cancer. J. Clin. Oncol. 2007, 25, 3877-3883. [CrossRef]

101. Prieto-Alhambra, D.; Javaid, M.; Servitja, S.; Arden, N.; Martinez-García, M.; Diez-Perez, A.; Albanell, J.; Tusquets, I.; Nogues, X. Vitamin D threshold to prevent aromatase inhibitor-induced arthralgia: A prospective cohort study. Breast Cancer Res. Treat. 2010, 125, 869-878. [CrossRef]

102. Garcia-Giralt, N.; Rodríguez-Sanz, M.; Prieto-Alhambra, D.; Servitja, S.; Torres-Del Pliego, E.; Balcells, S.; Albanell, J.; Grinberg, D.; Diez-Perez, A.; Tusquets, I.; et al. Genetic determinants of aromatase inhibitor-related arthralgia: The B-ABLE cohort study. Breast Cancer Res. Treat. 2013, 140, 385-395. [CrossRef]

103. Jemal, A.; Bray, F.; Center, M.M.; Ferlay, J.; Ward, E.; Forman, D. Global cancer statistics. CA Cancer J. Clin. 2011, 61, 69-90. [CrossRef] [PubMed]

104. de Groot, P.; Munden, R.F. Lung cancer epidemiology, risk factors, and prevention. Radiol. Clin. N. Am. 2012, 50, 863-876. [CrossRef] [PubMed]

105. LaPar, D.J.; Nagji, A.S.; Bhamidipati, C.M.; Kozower, B.D.; Lau, C.L.; Ailawadi, G.; Jones, D.R. Seasonal variation influences outcomes following lung cancer resections. Eur. J. Cardiothorac. Surg. 2011, 40, 83-90. [CrossRef] [PubMed]

106. Liu, Y.; Chen, W.; Hu, Z.B.; Xu, L.; Shu, Y.Q.; Pan, S.Y.; Dai, J.C.; Jin, G.F.; Ma, H.X.; Shen, H.B. Plasma vitamin $\mathrm{D}$ levels and vitamin $\mathrm{D}$ receptor polymorphisms are associated with survival of non-small cell lung cancer. Chin. J. Cancer Res. 2011, 23, 33-37. [CrossRef] [PubMed]

107. Kilkkinen, A.; Knekt, P.; Heliövaara, M.; Rissanen, H.; Marniemi, J.; Hakulinen, T.; Aromaa, A. Vitamin D status and the risk of lung cancer: A cohort study in Finland. Cancer Epidemiol. Biomark. Prev. 2008, 17, 3274-3278. [CrossRef]

108. Zhou, W.; Heist, R.S.; Liu, G.; Asomaning, K.; Neuberg, D.S.; Hollis, B.W.; Wain, J.C.; Lynch, T.J.; Giovannucci, E.; Su, L.; et al. Circulating 25-hydroxyvitamin D levels predict survival in early-stage non-small-cell lung cancer patients. J. Clin. Oncol. 2007, 25, 479-485. [CrossRef]

109. Zhou, W.; Suk, R.; Liu, G.; Park, S.; Neuberg, D.S.; Wain, J.C.; Lynch, T.J.; Giovannucci, E.; Christiani, D.C. Vitamin D is associated with improved survival in early-stage non-small cell lung cancer patients. Cancer Epidemiol. Biomark. Prev. 2005, 14, 2303-2309. [CrossRef]

110. Yokomura, K.; Suda, T.; Sasaki, S.; Inui, N.; Chida, K.; Nakamura, H. Increased expression of the 25-hydroxyvitamin $\mathrm{D}(3)$-1alpha-hydroxylase gene in alveolar macrophages of patients with lung cancer. J. Clin. Endocrinol. Metab. 2003, 88, 5704-5709. [CrossRef]

111. Mio, T.; Romberger, D.J.; Thompson, A.B.; Robbins, R.A.; Heires, A.; Rennard, S.I. Cigarette smoke induces interleukin-8 release from human bronchial epithelial cells. Am. J. Respir. Crit. Care. Med. 1997, 155, 1770-1776. [CrossRef]

112. Wu, X.; Cheng, J.; Yang, K. Vitamin D-related gene polymorphisms, plasma 25-hydroxy-vitamin D, cigarette smoke and non-small cell lung cancer (NSCLC) risk. Int. J. Mol. Sci. 2016, 17, 1597. [CrossRef] [PubMed]

113. Kong, J.; Xu, F.; Qu, J.; Wang, Y.; Gao, M.; Yu, H.; Qian, B. Genetic polymorphisms in the vitamin D pathway in relation to lung cancer risk and survival. Oncotarget 2015, 6, 2573-2582. [CrossRef] [PubMed]

114. Gronostajski, R.M. Roles of the NFI/CTF gene family intranscription and development. Gene 2000, 249, 31-45. [CrossRef] 
115. Gronostajski, R.M.; Adhya, S.; Nagata, K.; Guggenheimer, R.A.; Hurwitz, J. Site-specific DNA binding of nuclear factor I: Analyses of cellular binding sites. Mol. Cell Biol. 1985, 5, 964-971. [CrossRef]

116. Anderson, L.N.; Cotterchio, M.; Knight, J.A.; Borgida, A.; Gallinger, S.; Cleary, S.P. Genetic variants in vitamin d pathway genes and risk of pancreas cancer; results from a population based case-control study in Ontario, Canada. PLoS ONE 2013, 8, e66768. [CrossRef]

117. Arem, H.; Yu, K.; Xiong, X.; Moy, K.; Freedman, N.D.; Mayne, S.T.; Albanes, D.; Arslan, A.A.; Austin, M.; Bamlet, W.R.; et al. Vitamin D metabolic pathway genes and pancreatic cancer risk. PLoS ONE 2015, 10, e0117574. [CrossRef]

118. Grant, W.B. An estimate of premature cancer mortality in the U.S. due to inadequate doses of solar ultraviolet-B radiation. Cancer 2002, 94, 1867-1875. [CrossRef]

119. Grant, W.B. An ecologic study of cancer mortality rates in Spain with respect to indices of solar UVB irradiance and smoking. Int. J. Cancer 2007, 120, 1123-1128. [CrossRef]

120. Kinoshita, S.; Wagatsuma, Y.; Okada, M. Geographical distribution for malignant neoplasm of the pancreas in relation to selected climatic factors in Japan. Int. J. Health Geogr. 2007, 6, 34. [CrossRef]

121. Stolzenberg-Solomon, R.Z.; Jacobs, E.J.; Arslan, A.A.; Qi, D.; Patel, A.V.; Helzlsouer, K.J.; Weinstein, S.J.; McCullough, M.L.; Purdue, M.P.; Shu, X.O.; et al. Circulating 25-hydroxyvitamin D and risk of pancreatic cancer: Cohort Consortium Vitamin D Pooling Project of Rarer Cancers. Am. J. Epidemiol. 2010, 172, 81-93. [CrossRef]

122. Wolpin, B.M.; Ng, K.; Bao, Y.; Kraft, P.; Stampfer, M.J.; Michaud, D.S.; Ma, J.; Buring, J.E.; Sesso, H.D.; Lee, I.M.; et al. Plasma 25-hydroxyvitamin D and risk of pancreatic cancer. Cancer Epidemiol. Biomark. Prev. 2011, 21, 82-91. [CrossRef] [PubMed]

123. Clinckspoor, I.; Hauben, E.; Verlinden, L.; Van den Bruel, A.; Vanwalleghem, L.; Vander Poorten, V.; Delaere, P.; Mathieu, C.; Verstuyf, A.; Decallonne, B. Altered expression of key players in vitamin D metabolism and signaling in malignant and benign thyroid tumors. J. Histochem. Cytochem. 2012, 60, 502-511. [CrossRef] [PubMed]

124. Khadzkou, K.; Buchwald, P.; Westin, G.; Dralle, H.; Akerström, G.; Hellman, P. 25-hydroxyvitamin D3 1alpha-hydroxylase and vitamin D receptor expression in papillary thyroid carcinoma. J. Histochem. Cytochem. 2006, 54, 355-361. [CrossRef]

125. Sharma, V.; Fretwell, D.; Crees, Z.; Kerege, A.; Klopper, J.P. Thyroid cancer resistance to vitamin D receptor activation is associated with 24-hydroxylase levels but not the ff FokI polymorphism. Thyroid 2010, 20, 1103-1111. [CrossRef] [PubMed]

126. Bouillon, R.; Eelen, G.; Verlinden, L.; Mathieu, C.; Carmeliet, G.; Verstuyf, A. Vitamin D and cancer. J. Steroid Biochem. Mol. Biol. 2006, 102, 156-162. [CrossRef] [PubMed]

127. Penna-Martinez, M.; Ramos-Lopez, E.; Stern, J.; Hinsch, N.; Hansmann, M.L.; Selkinski, I.; Grunwald, F.; Vorlander, C.; Wahl, R.A.; Bechstein, W.O.; et al. Vitamin D receptor polymorphisms in differentiated thyroid carcinoma. Thyroid 2009, 19, 623-628. [CrossRef]

128. Alter, M.J. The epidemiology of acute and chronic hepatitis C. Clin. Liver Dis. 1997, 1, 559-568. [CrossRef]

129. Falleti, E.; Bitetto, D.; Fabris, C.; Cussigh, A.; Fontanini, E.; Fornasiere, E.; Fumolo, E.; Bignulin, S.; Cmet, S.; Minisini, R.; et al. Vitamin D receptor gene polymorphisms and hepatocellular carcinoma in alcoholic cirrhosis. World J. Gastroenterol. 2010, 16, 3016-3024. [CrossRef]

130. Cusato, J.; Boglione, L.; De Nicolò, A.; Favata, F.; Ariaudo, A.; Mornese Pinna, S.; Guido, F.; Avataneo, V.; Cantù, M.; Carcieri, C.; et al. Vitamin D pathway gene polymorphisms and hepatocellular carcinoma in chronic hepatitis C-affected patients treated with new drugs. Cancer Chemother. Pharmacol. 2018, 81, 615-620. [CrossRef]

131. Chang, E.T.; Canchola, A.J.; Cockburn, M.; Lu, Y.; Wang, S.S.; Bernstein, L.; Clarke, C.A.; Horn-Ross, P.L. Adulthood residential ultraviolet radiation, sun sensitivity, dietary vitamin D, and risk of lymphoid malignancies in the California Teachers Study. Blood 2011, 118, 1591-1599. [CrossRef]

132. Kelly, J.L.; Drake, M.T.; Fredericksen, Z.S.; Asmann, Y.W.; Liebow, M.; Shanafelt, T.D.; Feldman, A.L.; Ansell, S.M.; Macon, W.R.; Herr, M.M.; et al. Early life sun exposure, vitamin D-related gene variants, and risk of non-Hodgkin lymphoma. Cancer Causes Control 2012, 23, 1017-1029. [CrossRef] [PubMed]

133. Purdue, M.P.; Freedman, D.M.; Gapstur, S.M.; Helzlsouer, K.J.; Laden, F.; Lim, U.; Maskarinec, G.; Rothman, N.; Shu, X.O.; Stevens, V.L.; et al. Circulating 25-hydroxyvitamin D and risk of non-hodgkin lymphoma: Cohort consortium vitamin D pooling project of rarer cancers. Am. J. Epidemiol. 2010, 172, 58-69. [CrossRef] [PubMed] 
134. Fichna, M.; Żurawek, M.; Januszkiewicz-Lewandowska, D.; Gryczyńska, M.; Fichna, P.; Sowiński, J.; Nowak, J. Association of the CYP27B1C(-1260)A polymorphism with autoimmune Addison's disease. Exp. Clin. Endocrinol. Diabetes 2010, 118, 544-549. [CrossRef]

135. Lange, C.M.; Bojunga, J.; Ramos-Lopez, E.; von Wagner, M.; Hassler, A.; Vermehren, J.; Herrmann, E.; Badenhoop, K.; Zeuzem, S.; Sarrazin, C. Vitamin D deficiency and a CYP27B1-1260 promoter polymorphism are associated with chronic hepatitis $C$ and poor response to interferon-alfa based therapy. J. Hepatol. 2011, 54, 887-893. [CrossRef] [PubMed]

136. Bailey, R.; Cooper, J.D.; Zeitels, L.; Smyth, D.J.; Yang, J.H.; Walker, N.M.; Hyppönen, E.; Dunger, D.B.; Ramos-Lopez, E.; Badenhoop, K.; et al. Association of the vitamin D metabolism gene CYP27B1 with type 1 diabetes. Diabetes 2007, 56, 2616-2621. [CrossRef]

137. Wilke, R.A.; Simpson, R.U.; Mukesh, B.N.; Bhupathi, S.V.; Dart, R.A.; Ghebranious, N.R.; McCarty, C.A. Genetic variation in CYP27B1 is associated with congestive heart failure in patients with hypertension. Pharmacogenomics 2009, 10, 1789-1797. [CrossRef]

138. Goldberg, P. Multiple sclerosis: Vitamin D and calcium as environmental determinants of prevalence. Int. J. Environ. Stud. 1974, 6, 121-129. [CrossRef]

139. Beretich, B.D.; Beretich, T.M. Explaining multiple sclerosis prevalence by ultraviolet exposure: A geospatial analysis. Mult. Scler. 2009, 15, 891-898. [CrossRef]

140. Holick, M.F.; Cook, S.; Suarez, G.; Rametta, M. Vitamin D deficiency and possible role in multiple sclerosis. Eur. Neurol. Rev. 2015, 10, 131-138. [CrossRef]

141. Wang, Y.; Marling, S.J.; Zhu, J.G.; Severson, K.S.; DeLuca, H.F. Development of experimental autoimmune encephalomyelitis (EAE) in mice requires vitamin D and the vitamin D receptor. Proc. Natl. Acad. Sci. USA 2012, 109, 8501-8504. [CrossRef]

142. Chiuso-Minicucci, F.; Ishikawa, L.L.; Mimura, L.A.; Fraga-Silva, T.F.; França, T.G.; Zorzella-Pezavento, S.F.; Marques, C.; Ikoma, M.R.; Sartori, A. Treatment with vitamin D/MOG association suppresses experimental autoimmune encephalomyelitis. PLoS ONE 2015, 10, e0125836. [CrossRef]

143. Agnello, L.; Scazzone, C.; Lo Sasso, B.; Bellia, C.; Bivona, G.; Realmuto, S.; Brighina, F.; Schillaci, R.; Ragonese, P.; Salemi, G.; et al. VDBP, CYP27B1, and 25-hydroxyvitamin D gene polymorphism analyses in a group of Sicilian multiple sclerosis patients. Biochem. Genet. 2017, 55, 183-192. [CrossRef] [PubMed]

144. Ramagopalan, S.V.; Dyment, D.A.; Cader, M.Z.; Morrison, K.M.; Disanto, G.; Morahan, J.M.; Berlanga-Taylor, A.J.; Handel, A.; De Luca, G.C.; Sadovnick, A.D.; et al. Rare variants in the CYP27B1 gene are associated with multiple sclerosis. Ann. Neuro. 2011, 70, 881-886. [CrossRef] [PubMed]

145. Alcina, A.; Fedetz, M.; Fernández, O.; Saiz, A.; Izquierdo, G.; Lucas, M.; Leyva, L.; García-León, J.A.; del Mar Abad-Grau, M.; Alloza, I.; et al. Identification of a functional variant in the KIF5A-CYP27B1-METTL1-FAM119B locus associated with multiple sclerosis. J. Med. Genet. 2013, 50, 25-33. [CrossRef]

146. Jiang, T.; Li, L.; Wang, Y.; Zhao, C.; Yang, J.; Ma, D.; Guan, Y.; Zhao, D.; Bao, Y.; Wang, Y.; et al. The association between genetic polymorphism rs703842 in CYP27B1 and multiple sclerosis: A meta-analysis. Medicine (Baltimore) 2016, 95, e3612. [CrossRef]

147. Miller, W.L. Genetic disorders of vitamin D biosynthesis and degradation. J. Steroid Biochem. Mol. Biol. 2017, 165, 101-108. [CrossRef] [PubMed]

148. Zalewski, A.; Ma, N.S.; Legeza, B.; Renthal, N.; Flück, C.E.; Pandey, A.V. Vitamin D-dependent rickets type 1 caused by mutations in CYP27B1 affecting protein interactions with adrenodoxin. J. Clin. Endocrinol. Metab. 2016, 101, 3409-3418. [CrossRef] [PubMed]

149. Demir, K.; Kattan, W.E.; Zou, M.; Durmaz, E.; BinEssa, H.; Nalbantoğlu, Ö.; Al-Rijjal, R.A.; Meyer, B.; Özkan, B.; Shi, Y. Novel CYP27B1 gene mutations in patients with vitamin D-dependent rickets type 1A. PLoS ONE 2015, 10, e0131376. [CrossRef]

150. Georgakopoulou, E.A.; Achtari, M.D.; Achtaris, M.; Foukas, P.G.; Kotsinas, A. Oral lichen planus as a preneoplastic inflammatory model. J. Biomed. Biotechnol. 2012, 2012, 759626. [CrossRef]

151. Carrozzo, M.; Thorpe, R. Oral lichen planus: A review. Minerva Stomatol. 2009, 58, 519-537.

152. Kujundzic, B.; Zeljic, K.; Supic, G.; Magic, M.; Stanimirovic, D.; Ilic, V.; Jovanovic, B.; Magic, Z. Association of vdr, cyp27b1, cyp24a1 and mthfr gene polymorphisms with oral lichen planus risk. Clin. Oral Investig. 2016, 20, 781-789. [CrossRef] [PubMed] 
153. Zeljic, K.; Supic, G.; Stamenkovic Radak, M.; Jovic, N.; Kozomara, R.; Magic, Z. Vitamin D receptor, CYP27B1 and CYP24A1 genes polymorphisms association with oral cancer risk and survival. J. Oral. Pathol. Med. 2012, 41, 779-787. [CrossRef] [PubMed]

154. DeLuca, H.F.; Zierold, C. Mechanisms and functions of vitamin D. Nutr. Rev. 1998, 56, S4-S10. [CrossRef] [PubMed]

(C) 2020 by the authors. Licensee MDPI, Basel, Switzerland. This article is an open access article distributed under the terms and conditions of the Creative Commons Attribution (CC BY) license (http://creativecommons.org/licenses/by/4.0/). 